\title{
Palaeoclimate, glacier and treeline reconstruction based on geomorphic evidences in the Mongun-Taiga massif (south-eastern Russian Altai) during the Late Pleistocene and Holocene
}

\author{
Ganyushkin, Dmitry ; Chistyakov, Kirill ; Volkov, Ilya ; Bantcev, Dmitry ; Kunaeva, Elena ; Brandová, \\ Dagmar ; Raab, Gerald ; Christl, Marcus ; Egli, Markus
}

\begin{abstract}
Little is known about the extent of glaciers and dynamics of the landscape in south-eastern Russian Altai. The effects of climate-induced fluctuations of the glaciers and the upper treeline of the Mongun-Taiga mountain massif were, therefore, reconstructed on the basis of in-situ, multiannual observations, geomorphic mapping, radiocarbon and surface exposure dating, relative dating (such as Schmidthammer and weathering rind) techniques and palaeoclimate-modelling. During the maximal advance of the glaciers, their area was 26-times larger than now and the equilibrium line of altitude (ELA) was about $800 \mathrm{~m}$ lower. Assuming that the maximum glacier extent took place during MIS 4, then the average summer temperatures were $2.7^{\circ} \mathrm{C}$ cooler than today and the amount of precipitation 2.1 times higher. Buried wood trunks by a glacier gave ages between 60 and 28 cal ka BP and were found 600-700m higher than the present upper treeline. This evidences a distinctly elevated treeline during MIS $3 \mathrm{a}$ and c. With a correction for tectonics we reconstructed the summer warming to have been between 2.1 and $3.0^{\circ} \mathrm{C}$. During MIS 3c, the glaciated area was reduced to less than $0.5 \mathrm{~km}^{2}$ with an increase of the ELA of 310-470m higher than today. Due to higher precipitation, the glaciated area during MIS 3a was close to the current ELA. Exposure dating $\left({ }^{1} \mathrm{Be}\right)$ would indicate that the maximum glacier extension was 24 ka BP, but the results are questionable. From a geomorphic point of view, the maximum extent can more likely be ascribed to the MIS4 stage. We estimate a cooling of summer temperature of - 3.8 to $-4.2^{\circ} \mathrm{C}$ and a decrease in precipitation of $37-46 \%$ compared to the present-day situation. Samples of wood having an age of 10.6-6.2 cal ka BP were found about $350 \mathrm{~m}$ higher than the present treeline. It seems that the summer temperature was $2.0-2.5^{\circ} \mathrm{C}$ higher and annual precipitation was double that of the present-day. For that period, the reconstructed glaciation area was $1 \mathrm{~km}^{2}$ less than today. Three neoglacial glacier advances were detected. The glaciers covered about double the area during the Little Ice Age (LIA), summer cooling was $1.3^{\circ} \mathrm{C}$ with $70 \%$ of the present-day precipitation. The reconstructed amplitude of climatic changes and the shift of the altitudinal zones show that the landscape has reacted sensitively to environmental changes and that dramatic changes may occur in the near future.
\end{abstract}

DOI: https://doi.org/10.1016/j.quaint.2017.12.031

Posted at the Zurich Open Repository and Archive, University of Zurich ZORA URL: https://doi.org/10.5167/uzh-161504

Journal Article Accepted Version 
The following work is licensed under a Creative Commons: Attribution-NonCommercial-NoDerivatives 4.0 International (CC BY-NC-ND 4.0) License.

Originally published at:

Ganyushkin, Dmitry; Chistyakov, Kirill; Volkov, Ilya; Bantcev, Dmitry; Kunaeva, Elena; Brandová, Dagmar; Raab, Gerald; Christl, Marcus; Egli, Markus (2018). Palaeoclimate, glacier and treeline reconstruction based on geomorphic evidences in the Mongun-Taiga massif (south-eastern Russian Altai) during the Late Pleistocene and Holocene. Quaternary International: The Journal of the International Union for Quaternary Research, 470:26-37.

DOI: https://doi.org/10.1016/j.quaint.2017.12.031 
1 Palaeoclimate, glacier and treeline reconstruction based on geomorphic

2 evidences in the Mongun-Taiga massif (south-eastern Russian Altai) during the

3 Late Pleistocene and Holocene

4

5

Dmitry Ganyushkin a, ${ }^{\text {, }}$ Kirill Chistyakov ${ }^{a}$, Ilya Volkova, Dmitry Bantceva, Elena Kunaeva ${ }^{\text {, }}$, Dagmar Brandovác, Gerald Raabc ${ }^{c}$ Marcus Christl ${ }^{\mathrm{d}}$, Markus Eglic

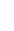

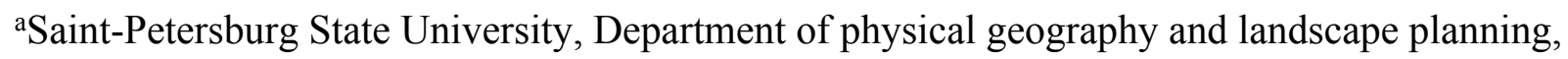
Russian Federation, Saint-Petersburg, 199178, 10 liniya V.O., h.33-35

bPushkin Leningrad State University, 10 Peterburgskoe shosse, St Petersburg (Pushkin), 196605 Russian Federation

'Department of Geography, University of Zurich, Winterthurerstrasse 190, CH-8057 Zurich, Switzerland

d'Laboratory of Ion Beam Physics, ETH Zurich, 8093 Zurich, Switzerland 5

Dmitry Ganyushkin (Corresponding author), Petersburg State University, Institute of Earth Sciences, Department of Physical Geography and Landscape Planning. Russian Federation, SaintPetersburg, 199178, 10 liniya V.O., h.33-35. tel.: +7(812)323-3913. E-mail: d.ganyushkin@spbu.ru 19

\footnotetext{
Abstract

Little is known about the extent of glaciers and dynamics of the landscape in south-eastern Russian Altai. The effects of climate-induced fluctuations of the glaciers and the upper treeline of the Mongun-Taiga mountain massif were, therefore, reconstructed on the basis of in-situ, multiannual observations, geomorphic mapping, radiocarbon and surface exposure dating, relative dating (such as Schmidt-hammer and weathering rind) techniques and palaeoclimate-modelling.
} 
27 During the maximal advance of the glaciers, their area was 26-times larger than now and the equilibrium line of altitude (ELA) was about $800 \mathrm{~m}$ lower. Assuming that the maximum glacier extent took place during MIS 4, then the average summer temperatures were $2.7{ }^{\circ} \mathrm{C}$ cooler than today and the amount of precipitation 2.1 times higher. Buried wood trunks by a glacier gave ages between 60 to $28 \mathrm{cal} \mathrm{ka} \mathrm{BP}$ and were found $600-700 \mathrm{~m}$ higher than the present upper treeline. This evidences a distinctly elevated treeline during MIS 3a and c. With a correction for tectonics we reconstructed the summer warming to have been between 2.1 and $3.0{ }^{\circ} \mathrm{C}$. During MIS $3 \mathrm{c}$, the glaciated area was reduced to less than $0.5 \mathrm{~km}^{2}$ with an increase of the ELA of $310-470 \mathrm{~m}$ higher than today. Due to higher precipitation, the glaciated area during MIS 3a was close to the current ELA. Exposure dating $\left({ }^{10} \mathrm{Be}\right)$ would indicate that the maximum glacier extension was $24 \mathrm{ka} \mathrm{BP}$, but the results are questionable. From a geomorphic point of view, the maximum extent can more likely be ascribed to the MIS4 stage. We estimate a cooling of summer temperature of -3.8 to $-4.2{ }^{\circ} \mathrm{C}$ and a decrease in precipitation of $37-46 \%$ compared to the present-day situation. Samples of wood having an age of $10.6-6.2 \mathrm{cal} \mathrm{ka}$ BP were found about $350 \mathrm{~m}$ higher than the present treeline. It seems that the summer temperature was $2.0-2.5^{\circ} \mathrm{C}$ higher and annual precipitation was double that of the present-day. For that period, the reconstructed glaciation area was $1 \mathrm{~km}^{2}$ less than today. Three neoglacial glacier advances were detected. The glaciers covered about double the area during the Little Ice Age (LIA), summer cooling was $1.3{ }^{\circ} \mathrm{C}$ with $70 \%$ of the present-day precipitation. The reconstructed amplitude of climatic changes and the shift of the altitudinal zones show that the landscape has reacted sensitively to environmental changes and that dramatic changes may occur in the near future.

9 Keywords: palaeoclimate reconstruction, Pleistocene, Holocene, arid mountains of Altai, treeline, glaciers 


\section{Introduction}

The Altai mountain region is situated at the border of Central Asia and Siberia and is an area having numerous geomorphic features that clearly display the variability of climatic conditions and landscape dynamics. The Altai mountains span four different countries (Russia, Mongolia, Kazakhstan and China). Due to the remoteness of the Altai mountains, this region is still very poorly studied in regard to the Holocene and Pleistocene landscape dynamics in general and glacier fluctuations in particular (Lehmkuhl et al., 2016). A general framework or pattern about the timing of the last glaciation, its maximum, the extension of the glaciers during the different time periods of the Late Pleistocene and Holocene and related altitudinal shifts of the vegetation zones are largely unknown. Some first ideas about former glaciations in the Altai were published in the late $19^{\text {th }}$ century (e.g., Mihaelis, 1886). Several dozens of stratigraphic schemes for the Quaternary have been created only for the Russian Altai. These schemes were based on differing theories about the number and extent of glacial epochs. For the Late Pleistocene, for example, some authors reconstructed one glaciation (Obruchev, 1914; Svitoch and Faustov, 1978; Butvilovskiy, 1993), one glaciation with two 'megastadials' (Okishev, 1982, 2011) or two separate glaciations (Devyatkin, 1965). The problem for the creation of a comprehensive scheme for the Pleistocene and Holocene glacial fluctuations was caused by the different approaches used, the absence of numerical ages for the moraines, the incongruity of results obtained from radiocarbon and other dating techniques and the spatial discontinuity of the reconstructions. The number of radiocarbon datings is small and they mostly covered an insufficiently long time interval. The available results of luminescence dating (Sheinkman, 2002; Agatova et al., 2009; Agatova and Nepop, 2017) or cosmogenic ${ }^{10} \mathrm{Be}$ and ${ }^{26} \mathrm{Al}$ surface exposure dating (Gribenski et al., 2016; Herget et al., 2017) remain partially controversial because older glacial forms often have not been dated, which rendered their attribution to maximal glacier extents of the LGM (Last Glacial Maximum) difficult.

In the Russian Altai, the history of Pleistocene and Holocene fluctuations of the glaciers and landscape dynamics is slightly better known because the climate is more humid, thus giving rise to 
more finds of datable organic remains. For the Mongolian Altai, geochronological results suggest large ice advances that correlate to the marine isotope stages (MIS) 4 and 2. This is in contrast to the results obtained from the central Mongolian Khangai mountains, where ice advances additionally occurred during MIS3. During the Pleistocene, glacial equilibrium-line altitudes (ELAs) were about 500 to $>1000 \mathrm{~m}$ lower in the more humid portion of the Russian and western Mongolian Altai, compared to $300-600 \mathrm{~m}$ in the drier ranges of the eastern Mongolian Altai (Lehmkuhl et al., 2016). In large parts of the Altai, Kanghai and north-eastern Tibetan plateau permafrost induces periglacial processes. Examples from late Holocene solifluction activity in the Altai, Khangai and north-eastern Tibetan plateau show a different intensity of solifluction processes during the late Holocene and Little Ice Age (LIA) due to a decrease in temperature and higher soil humidity (Lehmkuhl, 2016).

The problem of the unknown number of Pleistocene glaciations, glacial fluctuations and the timing of the maximal glacial extent(s) still remain unsolved. Sheinkman (2011) dated it to $105-115 \mathrm{ky}$ BP by using thermoluminescence (TL) and varve counting and referred it to MIS 5d. Several authors (Svitoch and Faustov, 1978; Borisov and Minina, 1989) dated the maximal glacial stage with $58 \pm 6.7 \mathrm{ka} \mathrm{BP}$ by using TL dating in the Chagan-Uzun key area. Okishev (2011) even referred it to the interval between $58 \pm 6.7$ and $32 \pm 4$ ka BP. MIS 3 ages were given for the Chinese Altai (Xu et al., 2009) and later re-dated to the MIS 4 stage (Zhao et al., 2013). Butvilovskiy (1993) attributed the maximum stage to about $18-20$ ka BP (Butvilovskiy, 1993). Recent surface exposure results $\left({ }^{10} \mathrm{Be}\right)$ gave an age for the glacial maximum at approximately $19.2 \mathrm{ka} \mathrm{BP}$ (Gribenski et al., 2016). For south-eastern Altai, most of the palaeogeographic information is related to the South-Chuya range (Agatova et al., 2012). Using radiocarbon data, Agatova et al. (2014) were able to trace former glacier fluctuations and upper tree limit variations for this part of the Altai for the last $3 \mathrm{ka}$. Glacier advances occurred between 2300 - 1700 cal BP and during the $13^{\text {th }}-19^{\text {th }}$ century (LIA). Further to the east, the climate becomes more arid, the vegetation is sparse and findings of organic fossils are rare. Consequently, this has also restricted the database on 
104 palaeo-information. In 1988, the University of St. Petersburg started to collect palaeoglaciologic 105 and palaeoclimatic data on the Mongun-Taiga mountain massif (eastern part of the Altai range).

106 The main goal of this paper is to develop a chronology of glaciation and to reconstruct fluctuations 107 of the glacial settings, climatic conditions and treeline variability in the Mongun Taiga during the 108 Late Pleistocene and Holocene.

\section{Study area}

111 The Mongun-Taiga mountain massif is situated in the south-eastern periphery of the Russian Altai 112 mountains (Fig. 1). It is located within the internal drainage basin of the Mongolian Great Lakes. 113 The highest peak has an elevation of $3971 \mathrm{~m}$ a.s.l. The main ridge stretches from southwest to 114 northeast, reaching $3000-3300 \mathrm{~m}$ in the western and eastern periphery and $3500-3970 \mathrm{~m}$ in the 115 central part. The climate of the massif is cold and arid. According to data of the closest 116 meteorological station Mugur-Aksy (1830 m a.s.l., $50^{\circ} 22^{\prime} 45^{\prime \prime} \mathrm{N}, 90^{\circ} 26^{\prime} 0^{\prime \prime} \mathrm{E}$; WMO code 117 362780: about $30 \mathrm{~km}$ to the north-east of the massif) the average annual precipitation is $160 \mathrm{~mm}$, 118 the mean summer temperature is $12.0^{\circ} \mathrm{C}$ and mean temperature about $-3^{\circ} \mathrm{C}$. Forest vegetation is 119 concentrated on the northern slopes of the massif with Larix Sibirica usually occurring between 1202000 and $2400 \mathrm{~m}$ a.s.l. The upper treeline varies between $2400 \mathrm{~m}$ on north-western slopes to 2300 121 on the north-eastern slopes. The upper treeline of the north-eastern slopes corresponds to an average summer temperature of $8.8^{\circ} \mathrm{C}$ (Chistyakov et al., 2012). Glacial relief forms such as cirques, Ushaped valleys or moraines are widely present at altitudes above $1800 \mathrm{~m}$ a.s.l. Three different morphological groups of moraines, representing glacial advances, can be distinguished.

125 Currently, there are 30 glaciers having a total area of $20.2 \mathrm{~km}^{2}$ within the massif. Valley glaciers 126 comprise over half of that area. The number of small hanging and cirque glaciers, however, is also 127 significant. One large proportion of the glaciers is found around the highest summit of the massif 128 (3971 $\mathrm{m}$ a.s.l.) and a smaller one to the west of the Tolaity valley having a maximal altitude of 3681 
130 glacier diverges radially and has a uniform accumulation zone. Usually, the largest glaciers develop

131 on the leeward, north-eastern slopes. The ice accumulation there is the result of a combination of 132 snow-drift and low insolation.

133 The vertical extension of glaciation is from 3970 to $2900 \mathrm{~m}$ a.s.l. The average ELA for the glaciers 134 of the Mongun-Taiga massif is at $3390 \mathrm{~m}$ a.s.l. The glaciers of the massif, however, are retreating 135 - as they are in many other parts of the world. The tendency of an accelerating retreat is 136 particularly well-documented for the largest glaciers during the last 10 years: for example, the 137 average rate of retreat of the Shara-Horagai glacier in 2013 - 2016 was $44.2 \mathrm{~m} /$ year (Ganiushkin et 138 al., 2015 and unpublished results).

\section{Materials and methods}

141 The investigations are based on in situ measurements and observations (glaciologic, glacio142 geomorphic, hydrological, meteorological, palaeogeographic) over the last 35 years that enabled a 143 modelling of palaeoclimate and timing of glaciation. The glaciologic and glacio-geomorphic field 144 observations included the delineation of the present-day glaciers using field mapping, route 145 observations, GPS-trekking of glacial termination and moraines, a geodetic survey of glacial snouts 146 and moraines, snow height measurements and duration of snow cover, evaluation of the ELA and 147 mass balance multiannual studies.

\subsection{Glacier observations}

150 The geodetic surveys (cf. Figs. 2 and 3) were performed on the Leviy Mugur glacier and its LIA 151 moraine (in 1994), on the snout and LIA moraines of the Shara-Horagai glacier in 1990 and 2013 152 and the Vostotschniy (east) Mugur (2012). In addition, aerial photos of 1966, Landsat-7 04.09.2001, 153 Landsat-8 12.08.2013 and Spot-5 2011-09-19 space imagery having a spatial resolution of 0.5 up to 15430 metres per pixel were used. Every scene was radiometrically normalised and geographically 155 referenced using orbital parameters. An automatic and systematic geometric correction of the raster 
156 data was applied by using a mathematical model of the view angles of the satellite camera and its

157 position at the moment of the scene collection (rigorous model). UTM/WGS 84 projection (zone

158 46) was applied as reference frame for georeferencing. The imagery was orthorectified using the 30

159 m ASTER GDEM v.2 digital elevation model (https://gdex.cr.usgs.gov/gdex/), and treated using a

160 moderate-sharpening filter for graphic quality preservation. Processing of space imagery and aerial

161 photographs was carried out using the photogrammetric software ERDAS Imagine.

162 The delineation of the glaciers and moraines was mapped manually. The minimum size of glaciers 163 to be mapped was $0.01 \mathrm{~km}^{2}$. The boundary line was mostly determined by direct observations.

3.2. Geomorphic observations and ELA determination

The following glacio-geomorphic features were mapped: cirques, riegel, troughs, trough shoulders and moraine ridges. This mapping resulted in the reconstruction of the position and margins of

168 former glaciers. Parameterisation of the present and reconstructed glaciers was performed using topographic maps at a scale of 1:100000 and 1:25000. The determination of the present-day ELA of the Mongun-Taiga was performed by using by direct observations (position of the snow line at the end of the ablation season during several years) and satellite imagery at the end of the ablation seasons.

\subsection{Meteorological and hydrological observations}

Meteorological and hydrological observations included in-situ measurements of temperature, precipitation, snow-melting and runoff in the Shara-Horagai (1990, 2013; observation stations at: $50.265292^{\circ} \mathrm{N} / 90.176922^{\circ} \mathrm{E}, 3130 m$ a,s.l.; $50.260703^{\circ} \mathrm{N} / 90.225562^{\circ} \mathrm{E}, 2780 m$ a.s.l.;

$17850.261678^{\circ} \mathrm{N} / 90.142461^{\circ} \mathrm{E}, 3800 m$ a.s.l.), Vostotschniy (East) Mugur (1993, 1995, 2010, 2011, 1792012 ; observation stations at: $50.335613^{\circ} \mathrm{N} / 90.225065^{\circ} \mathrm{E}, 2259 m$ a.s.l., $50.293760^{\circ} \mathrm{N} /$ $18090.181795^{\circ} \mathrm{E}, 2668 m$ a.s.l.) and the Praviy Mugur (1994; observation stations at: $90.101288^{\circ} \mathrm{E}$ 
182 measurements (air and ground temperature, precipitation, solar radiation, air humidity) were 183 continuously done during the ablation season at different elevational points: close to the upper 184 treeline; near the edges of glaciers; on glacial surfaces; on lateral moraines over the glacial snouts 185 and on the main summit of the massif. In addition, the data of the Mugur-Aksy meteorological 186 station were considered. Using all these datasets, a spatial extrapolation and modelling was 187 rendered possible. The vertical temperature gradient for the average summer temperature was $1880.69^{\circ} \mathrm{C} / 100 \mathrm{~m}$ and the pluviometric gradient was $7 \mathrm{~mm} / 100 \mathrm{~m}$ (Chistyakov et al., 2012). In addition, 189 a regional, empirical model (Chistyakov et al., 2012) of annual ablation $\left(a_{i}\right.$; mm water equivalent 190 per year) was obtained using the average summer temperature at ELA $\left(t_{0}\right)$ :

$a_{i}=36,14\left(t_{0}\right)^{2}+294,6 t_{0}+511,6$

\subsection{Numerical and relative dating of surfaces}

Dating of buried wood samples, peat and soils (humus) was done using the radiocarbon technique. Peat and wood samples were cleaned using an acid-alkali-acid (AAA) treatment. ${ }^{14} \mathrm{C}$ dating was performed at the KÖPPEN-Laboratory of the Saint-Petersburg State University. Radiocarbon dating was performed by using a Quantulus 1220 liquid scintillation spectrometer (Perkin Elmer, USA).

Dating of strongly-decomposed peat and humus (palaeosoils) was performed on the fraction that dissolves in hot $2 \% \mathrm{NaOH}$ (Arslanov et al., 1993). $\mathrm{A} \mathrm{V}_{2} \mathrm{O}_{5}$ coated $\mathrm{Al}_{2} \mathrm{O}_{3} \times \mathrm{SiO}_{2}$ catalyst has been employed for benzene synthesis.

200 The calendar ages were obtained using the OxCal 4.3 calibration program (Bronk Ramsey, 2001, 201 2009) based on the IntCal 13 calibration curve (Reimer et al., 2013). Calibrated ages are given in 202 the $1 \sigma$ range (minimum and maximum value for each). If not otherwise mentioned in the text, 203 calibrated years BP (cal BP) are used.

204 Furthermore, we tried to derive numeric age estimates for two end-moraines by dating rock 205 boulders using ${ }^{10} \mathrm{Be}$. However, the suitability of rock boulders was very limited. Two small 206 boulders (c. $0.3 \mathrm{~m}$ in height) were sampled and analysed for in situ ${ }^{10} \mathrm{Be}$. We were aware that the 
obtained ages would only be indicative (if that). The rock samples were pre-treated following the standard procedures. Samples were crushed and sieved and the quartz isolated by treating the 0.25 $\mathrm{mm}-0.6 \mathrm{~mm}$ fraction with aqua regia to destroy organic contaminations and any calcareous components. After a $1 \mathrm{~h}$ treatment with $0.4 \% \mathrm{HF}$, we used a floatation system to physically separate feldspar and mica components from the quartz. Remaining remnants of these were removed by repeated 4\% HF leaching steps. Once pure quartz was obtained, we added a ${ }^{9} \mathrm{Be}$-carrier solution and dissolved the samples in $40 \% \mathrm{HF}$. Be was isolated using anion and cation exchange columns followed by selective $\mathrm{pH}$ precipitation techniques (von Blanckenburg et al., 1996). The Be hydroxides were precipitated, dried, and calcinated for $2 \mathrm{~h}$ at $850{ }^{\circ} \mathrm{C}$ to $\mathrm{BeO}$. The ${ }^{10} \mathrm{Be} /{ }^{9} \mathrm{Be}$ ratios were measured at the ETH Laboratory Ion Beam Physics’ Accelerator Mass Spectrometry (AMS) facility using the ${ }^{10} \mathrm{Be}$ standard $\mathrm{S} 2007 \mathrm{~N}$ with a nominal value of ${ }^{10} \mathrm{Be} /{ }^{9} \mathrm{Be}=28.1 \times 10^{-12}($ Kubik and Christl, 2010; Christl et al., 2013). S2007N has been calibrated to the ${ }^{10} \mathrm{Be}$ standard ICN 01-5-1 of K. Nishiizumi and has a nominal ${ }^{10} \mathrm{Be} /{ }^{9} \mathrm{Be}$ value of $2.709 \times 10^{-11}$ (Nishiizumi et al., 2007). The $1 \sigma$ error of S2007N is $2.7 \%$ (Christl et al., 2013). Measured ${ }^{10} \mathrm{Be} /{ }^{9} \mathrm{Be}$ ratios were corrected for ${ }^{10} \mathrm{Be}$ contributed by the Be-carrier (blank value: $0.003 \mathrm{E}-12) .{ }^{10} \mathrm{Be}$ exposure ages were calculated using CRONUS-Earth (http://hess.ess.washington.edu/math/) version 2.3 with a ${ }^{10} \mathrm{Be}$ production rate of 4.01 ${ }^{10} \mathrm{Be}$ atoms/g SiO $2 /$ year (Borchers et al., 2016) and a ${ }^{10} \mathrm{Be}$ half-life of $1.387 \pm 0.012 \mathrm{Ma}($ Korschinek et al., 2010). The production rate was corrected for latitude and altitude using the scaling scheme of Stone (Stone, 2000) and corrected for sample thickness assuming an exponential depth profile (Brown et al., 1992) having an effective radiation attenuation length of $160 \mathrm{~g} \mathrm{~cm}^{-2}$ (Gosse and Phillips, 2001) and a rock density of $2.65 \mathrm{~g} \mathrm{~cm}^{-3}$. Effects of variations of the geomagnetic field on the ${ }^{10} \mathrm{Be}$ age are said to be negligible (Masarik et al., 2001; Pigati and Lifton, 2004).

In addition, relative-dating techniques were used to delineate a chronology of geomorphic deposits,

231 e.g., moraines. These techniques primarily are based on weathering patterns. On a polygon 232 (moraine) having an area of $10 \mathrm{~m}^{2}$, boulders having a diameter over $30 \mathrm{~cm}$ were marked and 
233 counted. Then properties were measured that included the occurrence of shear-strained boulders $(\mathrm{C}$,

$234 \%)$, the degree of embedment into finely-grained material $(\mathrm{B}, \%)$, weathering rind measurements $235(\mathrm{~W}, \mathrm{~mm})$, lichen coverage (L, \%), the number of boulders having a diameter over $30 \mathrm{~cm}(\mathrm{~N})$, rock 236 surface hardness $(\mathrm{R})$ and the proportion of flat-topped boulders $(\mathrm{F}, \%)$. The rock surface hardness 237 was measured using a Schmidt hammer, which measures the rebound value of a boulder (Matthews 238 and Shakesby, 1984; Goudie, 2006; Shakesby et al., 2006) and is a portable instrument originally 239 developed to test concrete quality in a non-destructive way (Schmidt, 1951). A spring-loaded bolt 240 impacting a surface yields a rebound- or R-value, which is proportional to the hardness 241 (compressive strength) of the rock surface. Applied in geomorphology, more-weathered surfaces 242 provide low R-values and less-weathered surfaces correspondingly high R-values (Böhlert et al., 243 2011). We used an N-type Schmidt hammer. Three measurements were done for each boulder (5 244 when there were larger differences between individual measurements) and then the average value 245 was registered. Measurements were carried out in the valleys of the upper tributaries of the Mugur 246 river on the north-eastern slope of the Mongun-Taiga massif at 19 sites where about 2500 boulders 247 were described and analysed.

\subsection{ELA and palaeoclimate modelling}

250 Modelling of palaeotemperature, palaeoprecipitation and ELA was done using the approach of 251 Ganyushkin (2015) and Glazyrin (1985) according to which the mass balance $(M)$ of a glacier at a 252 given altitude $Z$ close to $Z_{0}$ (ELA) is the following:

$253 \quad M(Z)=M\left(Z_{0}\right)+E \Delta Z$

254 where $E=$ energy of glacierisation (activity index or the mass-balance gradient at the ELA; IACS, 255 2011), $\Delta Z=Z-Z_{0}$. In case of changes of precipitation and temperature, the mass balance at the 256 altitude of interest can be calculated as: 
258 where $c\left(Z_{0}\right)=$ present accumulation at the ELA; $P=$ ratio of past annual precipitation to present-day

259 situation; $T=$ mean summer temperature; $a=$ ablation; $a\left(T\left(Z_{0}\right)+\Delta T\right)=$ ablation at the present-day

260 ELA in case of a change of the average summer temperature $\Delta T ; E_{n}=$ energy of glacierisation 261 (activity index) under new climatic conditions.

262 The altitude, where under the new climatic conditions the annual mass balance $M=0$, corresponds 263 to the new ELA $\left(Z_{0 n}\right)$ :

$\left.264 P \cdot c\left(Z_{f}\right)-a\left(T\left(Z_{0}\right)+\Delta T\right)\right)+E_{n}\left(Z_{0 n}-\Delta Z_{0}\right)=0$

265 Consequently, changes of the $\operatorname{ELA}\left(\Delta Z_{0}=Z_{0 n}-Z_{0}\right)$ are given by:

$266 \Delta Z_{0}=-\left(P \cdot c\left(Z_{0}\right)-a\left(T\left(Z_{0}\right)+\Delta T\right)\right) /\left(E_{n}\right)$

267 The ablation at the ELA is calculated using the extrapolated data from the Mugur-Aksy 268 meteorological station temperature (gradient $0.69{ }^{\circ} \mathrm{C} / 100 \mathrm{~m}$; cf. equation 1)). At the ELA, ablation 269 equals accumulation. The energy of glaciation $\left(E_{n}\right)$ can then be calculated by

$270 \quad E=P K(\Delta p / \Delta Z)+\Delta a / \Delta Z$

271 where $K=$ coefficient of snow concentration (at ELA $K=a / p$ ), $p=$ average annual precipitation at 272 ELA, $\Delta p / \Delta Z=$ gradient of precipitation, $\Delta a / \Delta Z=$ gradient of ablation.

273 Equation 5 contains 3 variables: $\Delta Z_{0}, P, \Delta T$. The first of them can be derived from palaeoglacial 274 reconstructions. The reconstruction of the ELA was done using the method proposed by Kurowsky 275 (1891):

$z_{0 n}=\left(z_{0} S+\Delta S\left(z_{1}+z_{2}\right) / 2\right) /(S+\Delta S)$

277 where $z_{f n}=$ reconstructed ELA, $\Delta S=$ difference between the area of the palaeoglacier and its 278 present-day area, $z_{1}=$ present-day altitude of the glacial snout and $z_{2}=$ altitude of the palaeoglacial 279 snout.

280 With an estimation of $\Delta Z_{0}$ for the reconstructed glaciers, equation 5 can be used to determine $P$ (if 281 we know $\Delta T$ ) and $\Delta T$ (if $P$ is known). Using this approach, scenarios can be calculated by assigning 282 a value to one of the unknown parameters. The choice of probable scenarios can be done on the 
283 basis on regional palaeoclimatic reconstructions or on regional statistical correlations between 284 precipitation and temperature. In the south-eastern Altai, a clear correlation between summer 285 precipitation and average summer temperature can be derived (based on meteorological stations of 286 the Altai (Ganyushkin, 2015). This can be expressed by the following empirical equation:

$287 \Delta T=2.245 \ln P-0.9779$

288 Another possibility is to use the correlation of monthly precipitation with monthly temperature from 289 the closest meteorological station Mugur-Aksy to Mongun-Taiga massif (Ganyushkin, 2015). The 290 empirical relationship looks as follows:

$291 P=0.6635 e^{0.0748 \Delta T}$

292 By combining equation (5) with (8) and (9), temperature and precipitation differences to the 293 present-day situation can be calculated. This procedure has been applied to reconstruct 294 palaeotemperatures and palaeoprecipitation. If the values of $P$ or $\Delta T$ for some time point are, 295 however, known from literature, calculations were directly carried out using equation (5). Having 296 the $\Delta T$ value, the difference between the present-day and the past upper treeline $\Delta F$ can be 297 calculated. Finds of buried wood gave, in addition, indications about the past upper treeline. 298 Assuming that the found wood was close to the treeline, then $\Delta T=\Delta F / G_{t}$, with $\Delta F=$ difference 299 between the altitude of the find and the altitude of the current treeline, $G_{t}=$ present-day altitudinal 300 gradient of temperature.

301 The obtained $\Delta Z_{0}$ and values of ELA and treeline variations should be corrected for tectonic shifts. In several parts, the Altai mountains are tectonically very active. This activity led to the dislocations of quaternary sediments (e.g., the northern bank of the upper flow of Shara-Horagai). Recent 304 earthquakes having a magnitude of $7-8$ took place in the area of the Mongun-Taiga massif (Actit305 Nur earthquake $19^{\text {th }}$ of October 1938 and Ureg-Nur earthquake $15^{\text {th }}$ of May 1970). Tectonic movements during the Late Pleistocene are indicated by indirect traces, e.g. the presence of faults with a vertical amplitude of up to $500 \mathrm{~m}$ (near the river Shara-Horagay), the occurrence of hanging valleys $(300-400 \mathrm{~m})$, or the presence of post-glacial erosional trenches with a depth of up to 500 
$\mathrm{m}$. From this the tectonic uplift can be roughly estimated with about $400 \mathrm{~m}$ for the last $75 \mathrm{ka}$. This corresponds to an uplift rate of about $5.3 \mathrm{~mm} /$ year.

\section{Results}

\subsection{Geomorphic patterns and glacier extension}

The first group (group I) of moraines is composed of a bluish-grey sandy material, having a large number of rounded boulders, mostly granite. Its surface is hummocky-like, with many small, round thermokarst depressions and lakes. These forms are located at the transition from U-shaped valleys to the intermountain depressions, i.e. at altitudes of $1800-2200 \mathrm{~m}$ a.s.l. In some valleys, these moraines can be traced on trough shoulders until the cirques (at an altitude of about $3100 \mathrm{~m}$ a.s.l.). Furthermore, these moraines can be subdivided into several stages: the oldest holds the greatest area but, in some places, the terminal moraines of the youngest stage break through the older ones. The moraines of group II are situated within the troughs, reaching $2100-2200 \mathrm{~m}$ a.s.l. at their lowest extension. Their composition is similar to the first group. These are typical moraines of a valley glaciation. The moraines show erosion in many places. Some moraines still dam lakes in the tongue basin, especially the youngest of these moraines. Lateral moraines of this group can be traced on trough shoulders up to the cirques to an altitude of about $2600-2700 \mathrm{~m}$ a.s.l., but $50-150 \mathrm{~m}$ below the previous group. The moraines of group III are characterised by coarse angular stony material intersected with sand and clay deposits. These types of moraines exhibit 3 stages that are usually adjacent to each other or even overlap each other. They mostly form sediment complexes in the upper part of troughs next to the present-day glaciers. These moraine complexes are usually bare of vegetation or slightly covered by pioneer vegetation; they have steep fronts. Glacial ice is sometimes exposed by thermokarst. These moraines are almost unaffected by erosion.

Although nowadays the glaciers mostly have a north-eastern aspect, the ancient moraines are more extensive on the southern slopes of the massif (Fig. 2). According to our reconstruction, the glaciers 
335 of the southern and south-eastern slopes had a length of up to $30-35 \mathrm{~km}$ during the LGM, while on

336 the northern slopes they had a length less than half of that. At the same time, the glacial termini 337 were $300-400 \mathrm{~m}$ lower on the southern slopes than on the northern slopes. Such a disproportion 338 could only have been caused by a higher moisture flux from the south and/or due to snow drifting 339 from the north-facing slopes.

\subsection{Dating of surfaces}

\section{Relative chronology}

343 The results of relative dating are given in Table 1. Both variables, shear-strained boulders (C) and 344 their embedment into the finely-grained material (B), increase proportionally along the 345 morphological groups of moraines (increasing values from III to I; Table 1). Also, the proportion of 346 flat-topped boulders (F) increases in the same order. The rebound values and the weathering rind 347 thicknesses show that the surface of the moraine groups I and II were the most weathered. From a 348 stratigraphic point of view, moraine group I must be older than moraine group II. This trend is best 349 reflected by the parameters $\mathrm{C}, \mathrm{B}$ and $\mathrm{F}$. This means that the cracking of larger boulders and their 350 embedment into the fine material are suitable processes to describe the long-term evolution of 351 moraines. The disintegration of smaller boulders on moraine surfaces or their progressive coverage 352 by finer sediments and soils, the coverage of the boulders with lichens and the flattening of the large 353 boulders are active processes at the early stage of moraine evolution. Rebound values (R) rapidly 354 decreased during the early stage of moraine evolution. The slight increase of these values for the 355 oldest moraine group could have been caused by the disintegration of less solid boulders and the 356 preservation of the more resistant part. Chemical weathering (oxidation, ferruginisation) in 357 conditions with low precipitation strongly depends on local differences in moisture content. 358 Usually, slightly thicker weathering rinds were measured near creeks (higher air humidity; in 359 general $1-2 \mathrm{~mm}$ thicker weathering rinds compared to drier conditions; data not shown). This 360 might have slightly biased the temporal trend of weathering rind thickness. 
Table 1

363 Relative dating of moraines of the Mongun-Taiga massif. I, II, III correspond to the morphological 364 moraine groups (Fig. 3).

\begin{tabular}{lllllllll}
\hline $\begin{array}{l}\text { Moraine } \\
\text { group }\end{array}$ & Number of polygons & $\mathrm{N}_{1} / \mathrm{N}_{2}{ }^{1)}$ & $\mathrm{C}, \%^{2)}$ & $\mathrm{B}, \%{ }^{3)}$ & $\mathrm{R}{ }^{4)}$ & $\mathrm{W}, \mathrm{mm}^{5)}$ & $\mathrm{F}, \%{ }^{6)}$ & $\mathrm{L}, \%{ }^{7)}$ \\
\hline I & 5 & 0.20 & 13.9 & $73.7 \pm 2.50$ & $44.7 \pm 1.63$ & 7.0 & 33.2 & 56.8 \\
II & 5 & 0.33 & 7.0 & $66.3 \pm 1.83$ & $40.4 \pm 1.80$ & 10.3 & 32.1 & 79.2 \\
III & 9 & 0.03 & 3.3 & $49.3 \pm 1.57$ & $51.3 \pm 2.62$ & 4.8 & 3.7 & 29.0 \\
\hline
\end{tabular}

\section{Radiometric chronology}

Direct dating of the moraines was difficult. Dating of warm periods during interstadials can help to fix glacial advances to a time interval. The minimal age for the warm period after the advance of the earliest stage of the third moraine group (3141 - 2776 cal BP; Table 2) was measured in the Praviy (right) Mugur valley (soil on the surface of a grass-covered moraine, adjacent to a younger bare moraine complex, index 11 in Fig. 3 and Table 2). There is also a high probability that the buried wood having an age $3697-3495 \mathrm{cal} \mathrm{BP}$ (index 7; Fig. 3), and found about $50 \mathrm{~m}$ above the presentday upper treeline, refers to this warm phase. Another time marker is a buried soil having an age of $5881-5326$ cal BP (index 8; Table 2, Fig. 3) that was found in the Shara-Horagai valley where the river cuts a moraine. This means that one (or maybe two) glacial advance(s) occurred between 5.5 to $3.6 \mathrm{ka}$ cal BP. This period can be referred to the earliest glacial advance of the Neoglacial period (cooling period that started after the Holocene Climatic Optimum, Akkem stage of Altai glaciers).

A warmer period obviously ended about $1.2 \mathrm{ka}$ BP indicated by a buried soil (1293 - 1089 cal BP;

38715 in Fig. 3). The maximum advance of the LIA glaciers was about $1810-1820$ AD (Ganiushkin et al., 2015) according to dendrochronological measurements. 
389 The warm period preceding the Neoglacial was characterised by a rise of the upper treeline to a

390 level of $300-400 \mathrm{~m}$ higher than today. Several finds of ancient wood having $10180-10580$

391 (sample site 5; Fig. 3), 9245 - 9000 (sample site 6) and 6350 - 6170 cal BP (sample site 5; Table 2)

392 indicate this shift. The dating of peat, wood and charcoal (Table 2 and Fig. 3; sample sites 13, 14,

393 15) indicates that relatively warm and/or moist conditions seem to have existed in the mid394 Holocene. According to fossil wood finds having an age of $31436-31178$ and $29537-28759$ cal 395 BP (sample sites 3 and 4; Table 2) at altitudes of 1000 and $500 \mathrm{~m}$ above the current upper treeline, 396 another warm period seems to have existed even before the Last Glacial Maximum (LGM). Such a 397 rise of the treeline must have been accompanied by a drastic reduction of the glaciers to a length 398 smaller than the present-day situation. The moraines of group II most likely refer to the period 399 between about 10 and $29 \mathrm{ka}$ cal BP and, therefore, correspond to MIS 2 (see below). The ancient 400 wood remains (28.7 - $31.4 \mathrm{ka}$ cal BP) are probably part of the MIS 3 warm period. There are 401 several other finds of buried trunks of Larix Sibirica (Fig. 4) having an age of 43 to about 60 ka cal 402 BP that can be found $600 \mathrm{~m}$ higher than the present-day upper treeline (sample sites 1 and 2, Table 403 2; Fig. 3) that support this hypothesis. Voelker and workshop participants (2002) dated MIS 3 to 404 between 59 and $29 \mathrm{ka} \mathrm{BP}$ and Pettitt and White (2012) to between 59 and $24 \mathrm{ka}$ BP. The moraines 405 of group I were deposited before MIS 3 and, therefore, correspond to MIS 4 or older (Fig. 3).

\section{Table 2}

408 Radiocarbon data from the Mongun-Taiga massif.

\begin{tabular}{|c|c|c|c|c|c|c|c|}
\hline $\begin{array}{l}\text { Sampli } \\
\text { ng site } \\
\text { (cf. } \\
\text { Fig. 3) }\end{array}$ & $\begin{array}{c}\text { Laboratory } \\
\text { ID }\end{array}$ & $\begin{array}{l}\text { Altitude } \\
\text { (m) }\end{array}$ & $\begin{array}{l}\text { Material } \\
\text { (cf. Fig. 3) }\end{array}$ & ${ }^{14} \mathrm{C}$ age \pm error & $\begin{array}{c}\text { Calibrated age } \\
(1 \sigma), \text { cal BP }\end{array}$ & $\begin{array}{c}\text { Climate } \\
\text { interpretation }\end{array}$ & Source \\
\hline 1 & LU-3666 & 2915 & wood (A) & $57810 \pm(\geq 1820)$ & c. $60000-56000$ & warm & this paper \\
\hline 2 & LU-5822 & 2965 & wood (A) & $39300 \pm 700$ & $43688-42567$ & warm & this paper \\
\hline 3 & KI-912 & 3300 & wood (A) & $27500 \pm 180$ & $31436-31178$ & warm & $\begin{array}{c}\text { (Revushkin, } \\
\text { 1974) }\end{array}$ \\
\hline 4 & KI-913 & 2800 & wood (A) & $25100 \pm 160$ & $29537-28759$ & warm & $\begin{array}{c}\text { (Revushkin, } \\
\text { 1974) }{ }^{1)}\end{array}$ \\
\hline 5 & SOAN 8116 & 2700 & wood (A) & - & $10580-10180$ & warm, humid & $\begin{array}{c}\text { (Nazarov et } \\
\text { al., 2012) }\end{array}$ \\
\hline 6 & LU-6949 & 2640 & wood (A) & $8140 \pm 80$ & $9245-9000$ & warm & this paper \\
\hline 5 & SOAN 8117 & 2700 & wood (A) & - & $6350-6170^{2)}$ & warm, humid & (Nazarov et \\
\hline
\end{tabular}




\begin{tabular}{|c|c|c|c|c|c|c|c|}
\hline 13 & LU-3219 & 2460 & peat (C) & $4920 \pm 80$ & $5740-5588$ & humid & al., 2012) \\
\hline 8 & LU-7283 & 2960 & soil (B) & $4860 \pm 190$ & $5881-5326$ & warm & this paper \\
\hline 9 & LU-5830 & 2350 & $\begin{array}{c}\text { charcoal in } \\
\text { soil (B) }\end{array}$ & $4570 \pm 80$ & $5445-5054$ & warm & this paper \\
\hline 14 & LU-6451 & 2350 & peat (C) & $4110 \pm 100$ & $4819-4522$ & humid & this paper \\
\hline 10 & LU-7284 & 2855 & soil (B) & $3580 \pm 280$ & $4290-3515$ & warm & this paper \\
\hline 7 & LU-6452 & 2350 & wood (A) & $3370 \pm 70$ & $3697-3495$ & warm, humid & this paper \\
\hline 11 & LU-8382 & 2675 & soil (B) & $2820 \pm 150$ & $3141-2776$ & warm & this paper \\
\hline 12 & LU-6818 & 2630 & soil (B) & $1280 \pm 80$ & $1293-1089$ & warm & this paper \\
\hline 15 & LU-6817 & 2535 & peat (C) & $1190 \pm 60$ & $1224-1009$ & warm, moist & this paper \\
\hline
\end{tabular}

${ }^{1)} \mathrm{A} \delta^{13} \mathrm{C}$ correction was at that time not performed. A $\delta^{13} \mathrm{C}$ value of $-25 \%$ was assumed for the correction of the ${ }^{14} \mathrm{C}$ data.

412 2) Original data $10380 \pm 200 \mathrm{cal} \mathrm{BP}$

413 3) Original data $6260 \pm 90$ cal BP

414

416 Table 3

417 Sample properties and ${ }^{10} \mathrm{Be}$ surface ages. Latitude and longitude are in WGS84 coordinates.

418 Shielding correction includes the effects caused by mountain topography, dip and strike of the

419 various boulder surfaces.

\begin{tabular}{|c|c|c|c|c|c|c|c|c|c|c|c|c|}
\hline $\begin{array}{l}\text { Sample } \\
\text { name }\end{array}$ & $\begin{array}{l}\mathrm{ETH} / \mathrm{UZH} \\
\text { label }\end{array}$ & $\begin{array}{l}\text { Latitude } \\
\text { (DD) }\end{array}$ & $\begin{array}{c}\text { Longitude } \\
\text { (DD) }\end{array}$ & $\begin{array}{l}\text { Elevation } \\
\text { (m a.s.l.) }\end{array}$ & $\begin{array}{c}\text { Thickness } \\
(\mathrm{cm})\end{array}$ & $\begin{array}{l}\text { Shielding } \\
\text { factor }\end{array}$ & $\begin{array}{c}\text { Quartz } \\
\text { (g) }\end{array}$ & $\begin{array}{c}\text { Carrier } \\
(\mathrm{mg})\end{array}$ & $\begin{array}{c}{ }^{10} \mathrm{Be} \\
\text { content }^{\mathrm{a}} \\
(\text { atoms g-1) }\end{array}$ & $\begin{array}{c}\text { Uncertainty } \\
{ }^{10} \text { Be content }{ }^{\mathrm{b}} \\
\left(\text { atoms g }{ }^{-1}\right)\end{array}$ & $\begin{array}{l}\text { Exposure } \\
\text { age }^{\mathrm{c}, \mathrm{e}} \\
\text { (a) }\end{array}$ & $\begin{array}{c}\text { Uncertainty }, \mathrm{e} \\
(+/-\mathrm{a})\end{array}$ \\
\hline 16 & MIS2 & 50.337 & 90.162 & 2500 & 3 & 0.983 & 20.61 & 0.35 & $3.35 \mathrm{E}+05$ & $1.42 \mathrm{E}+04$ & 11229 & $1083(482)$ \\
\hline 17 & MIS4 & 50.343 & 90.154 & 2408 & 3 & 0.947 & 26.17 & 0.349 & $6.33 \mathrm{E}+05$ & $2.63 \mathrm{E}+04$ & 23633 & $2306(1014)$ \\
\hline
\end{tabular}

$420 \quad{ }^{a}$ We used a density of $2.65 \mathrm{~g} \mathrm{~cm}^{-3}$ for all samples.

$421 \quad{ }^{b}$ Uncertainty includes AMS measurements errors and statistical counting error.

${ }^{c}$ We used a rock erosion rate of $1 \mathrm{~mm} / \mathrm{ka}$

${ }^{\mathrm{d}}$ External (internal) uncertainty

e Surface exposure ages were calculated with the CRONUS-Earth online calculators (http://hess.ess.washington.edu/, Balco et al., 2008 and version 2.3) and using the scaling scheme for spallation based on Lal (1991)/Stone (2000).

427 Although the obtained ${ }^{10} \mathrm{Be}$ ages of the moraine boulders would fit with an LGM around 24 ka and

428 a stage of the Youngest Dryas (Table 3), the ages seem to be too young. The age (moraine group

429 III) of these boulders does not fit with their topographic and geomorphic position (moraine group I).

430 Either the moraine groups II and III are very close together (where the boulder samples were taken;

431 but then the geomorphic map would have to be reconsidered) and consequently are difficult to be

432 discerned separately or the obtained ages are biased due to an exhumation of the boulders over time.

433 Both possibilities are likely — however, the likelihood of boulder exhumation is in this permafrost-

434 overprinted region higher (and thus, the measured ages too young). The height of the boulders (30-

$43540 \mathrm{~cm}$ ) was unfortunately very low and, consequently, disturbances may have occurred. 
4.3. Palaeoclimate-modelling and ELA reconstructions

438 During the maximal stage, the total area of glacier cover of the massif was $516 \mathrm{~km}^{2}$. The maximum 439 advance of the glaciers probably occurred about $75 \mathrm{ka}$ ago (end of MIS 5a, beginning of MIS4) 440 when an abrupt cooling (about $12{ }^{\circ} \mathrm{C}$ ) caused the onset of the last glacial period in Tibet 441 (neighbouring region) according to ice-core records (Thompson, 1997; Shi et al., 2008). We 442 assumed a tectonic uplift rate of about $5.3 \mathrm{~mm} /$ year for the correction of the palaeotopography 443 (Table 4). The glaciers moved from the troughs to the flat piedmonts and joined each other at the 444 piedmont of the mountains (Fig. 2). The average ELA depression $\Delta Z_{0}$ for this stage was about 800 $445 \mathrm{~m}$. Based on our results (Tables 2 and 4), the reconstructed glaciated area was $342 \mathrm{~km}^{2}$ during the 446 second stage of MIS 4 (moraine group I). During the third stage of MIS 4, the glaciated area was 447 similar. Some of the glaciers even overlapped the moraines of the maximal stage (1790 $\mathrm{m}$ a.s.l. in 448 the Orta-Shegetei valley). These small stages could be differentiated from a topographical and 449 geomorphological point of view.

450 During the MIS 2 maximum (moraine group II), the glacial area was about $318 \mathrm{~km}^{2}$. Valley glaciers 451 prevailed. The aspect asymmetry of glaciation was similar to that of MIS 4. The average ELA 452 depression was about $660 \mathrm{~m}$. In each of the subsequent 4 stages, the glaciated area was lower than 453 that of the previous stage (Table 4).

\section{Table 4}

456 Reconstruction of the vertical fluctuation of the upper treeline $\Delta F$ ( $\Delta F^{*}$ with tectonic corrections), 457 ELA depression $\Delta Z_{0}\left(\Delta Z_{0} *\right.$ with tectonic correction), precipitation $P \%$ (\% of the present-day 458 situation) and temperature difference to the present-day situation $\Delta T$.

\begin{tabular}{lcccccc}
\hline $\begin{array}{l}\text { Period (and ages of } \\
\text { samples of Table 2) }\end{array}$ & $\begin{array}{c}\Delta F \\
(\mathrm{~m})\end{array}$ & $\begin{array}{c}\Delta F^{*} \\
(\mathrm{~m})\end{array}$ & $\begin{array}{c}\Delta Z_{0} \\
(\mathrm{~m})\end{array}$ & $\begin{array}{c}\Delta Z_{0}{ }^{*} \\
(\mathrm{~m})\end{array}$ & $P \%$ & $\begin{array}{c}\Delta T \\
{ }^{\circ} \mathrm{C}\end{array}$ \\
\hline \multirow{2}{*}{ MIS 4 } & & & & & & \\
MIS 4 maximum & & -390 & -800 & -1200 & 210 & -2.7 \\
MIS 4 stage 2 & & -505 & -790 & -1163 & 105 & -3.5 \\
\hline
\end{tabular}




\begin{tabular}{|c|c|c|c|c|c|c|}
\hline MIS 4 stage 3 & & -465 & -790 & -1145 & 95 & -3.2 \\
\hline \multicolumn{7}{|l|}{ MIS 3} \\
\hline $56000-60000$ cal BP & 615 & 309 & - & 245 & 100 & 2.1 \\
\hline $43688-42567$ cal BP & 665 & 470 & - & 332 & 100 & 3.0 \\
\hline $31436-31178$ cal BP & 1000 & $854 ?$ & - & 458 & 200 & $5.9 ?$ \\
\hline $29537-28759$ cal BP & 500 & 356 & - & 102 & 200 & 2.5 \\
\hline \multicolumn{7}{|l|}{ MIS 2} \\
\hline MIS 2 maximum & & -550 & 658 & -758 & 46 & -3.8 \\
\hline MIS 2 stage 2 & & -536 & 643 & -731 & 46 & -3.7 \\
\hline MIS 2 stage 3 & & -507 & 578 & -655 & 43 & -3.5 \\
\hline MIS 2 stage 4 & & -493 & 523 & -594 & 43 & -3.4 \\
\hline MIS 2 stage 5 & & -478 & 485 & -551 & 46 & -3.3 \\
\hline \multicolumn{7}{|l|}{ Holocene } \\
\hline $10580-10180$ cal BP & 400 & 345 & - & 84 & 200 & 2.4 \\
\hline $9245-9000 \mathrm{cal} \mathrm{BP}$ & 340 & 292 & & 37 & 200 & 2.0 \\
\hline $6350-6170 \mathrm{cal} \mathrm{BP}$ & 400 & 367 & - & 98 & 200 & 2.5 \\
\hline $5881-5326$ cal BP & & 22 & - & 21 & 100 & 0.15 \\
\hline \multicolumn{7}{|l|}{ Akkem stage } \\
\hline $5326-3697$ cal BP & - & -145 & 151 & -174 & 110 & -1.0 \\
\hline $3697-3495$ cal BP & 50 & 31 & - & 2 & 110 & 0.2 \\
\hline \multicolumn{7}{|l|}{ Historical stage } \\
\hline 3495 - 1293 cal BP & & -58 & 120 & -129 & 119 & -0.4 \\
\hline $1293-1009$ cal BP & & 0 & 0 & 0 & 100 & 0 \\
\hline \multicolumn{7}{|l|}{ LIA } \\
\hline $1810-1820 \mathrm{AD}$ & & -188 & 120 & -121 & 73 & -1.3 \\
\hline
\end{tabular}

\section{Discussion}

5.1. Climate and treeline variability during the Late Pleistocene

465 According to the topographic position of the observed moraines, we assume that the maximum

466 glacier advance occurred during MIS 4. This would agree with Zhao et al. (2013) who also dated 467 the maximum glacial extension in the Chinese Altai to MIS 4. Surface exposure dating resulted in 468 an estimated age of about $24 \mathrm{ka}$, but this result seems questionable. For the exposure date to 469 represent the true formation or abandonment age of the landform as closely as possible, the sampled 470 object (boulder, clasts or bedrock) surface must have i) undergone single-stage exposure (no pre471 exposure/inheritance); ii) been continuously exposed in the same position (not shifted); iii) never 472 been covered and iv) undergone only minimal surface weathering or erosion (not spalled) (Ivy-Ochs 
473 and Kober, 2008). The dated boulders would appear probably to have been exhumated and 474 consequently do not match point iii). Data of the Gulia glacier show that the lowest temperatures 475 during MIS 4 occurred c. $70 \mathrm{ka} \mathrm{BP}$. Thereafter, temperature gradually increased until $57 \mathrm{ka}$ BP and 476 the beginning of MIS 3. The coldest period was accompanied by a higher aridity, a decrease of the 477 forest vegetation and a rapid ( $2-2.5$ times quicker) increase in dust accumulation on glaciers 478 (Klinge, 2001; Shi et al., 2008). We therefore suggest that the maximal glacial advance in the 479 Mongun-Taiga massif happened about 75 ka BP (Fig. 5). Devyatkin (1981) and Murzaeva et al. 480 (1984) calculated that annual precipitation was during MIS $41.5-3$ times higher in the 481 Mongolian Great Lake Depression. Based on pollen analyses from the north-western Altai (Anui 482 dva), Malaeva (1995) estimated a precipitation rate of about $400-700 \mathrm{~mm} / \mathrm{a}$. The topographic 483 asymmetry of glaciation is noteworthy and indicates that the southern slopes accumulated a larger 484 amount of snow (and therefore had either more precipitation or very substantial additions due to 485 wind drift).

486 As the glaciers advanced worldwide and the global climate became colder, the oceans cooled down 487 c. 72 ka ago (Ruddiman and McIntyre, 1981). The temperature contrasts between the continents and 488 the oceans decreased, but the temperature contrasts between the poles and the equator grew. That 489 led to an increased meridional circulation, blocking the zonal atmospheric transfer and terminated 490 glacial growth in continental mid-latitude areas, although the minimum temperatures $\left(\Delta T=-3.5^{\circ} \mathrm{C}\right.$, 491 Table 4, Fig. 4) probably occurred about $70 \mathrm{ka} \mathrm{BP}$. Under these conditions, the upper treeline was at 492 about 1500 - $1600 \mathrm{~m}$ a.s.l., and the probability was low that a forest vegetation existed in the 493 Mongun-Taiga massif.

494 MIS 3 is generally considered to have been a warmer period than MIS 4 or MIS 2 period (Van 495 Meerbeeck et al., 2008). However, there is evidence of some considerable climatic fluctuations 496 within the MIS 3 (Shi et al., 2008). According to our reconstruction for the interval of about 58 $49743.5 \mathrm{ka} \mathrm{BP}, \Delta T$ in the Mongun-Taiga massif reached +2.1 to $+3.0{ }^{\circ} \mathrm{C}$ (Table 4). This is in agreement 498 with the reconstructions of the Gulia glacial kerns in Tibet (Shi et al., 2008), according to which the 
early MIS $3(60-54 \mathrm{ka} \mathrm{BP})$ was about $3{ }^{\circ} \mathrm{C}$ warmer than today. Nonetheless, some glacier advances also occurred during MIS 3: e.g., in the Northern and Eastern Tibet (between 41 and 49 ka ago; Lehmkuhl and Liu, 1994). In the Khangai mountains the MIS 3 glacial advance (40 - 35 ka ago) is even considered as the largest (Rother et al., 2014). Also for the Altai region, the situation does not seem that clear. In the Kanan basin, the same moraines for a maximum glacier advance gave differing ages (Xu et al., 2009). It is, therefore, unclear if a further glacial advance occurred in the Mongun-Taiga massif in MIS 3. Several finds of ancient wood indicate a rather warmer climate. We therefore suggest that if any glacier advance took place, then it is more likely that it took place during the interval 43.5 - 27 ka ago and was less distinct than the MIS 4 and MIS 2 advances (Fig. $5)$.

There are no palaeoecological reconstructions that allow an estimation of the precipitation rates in the Mongun-Taiga massif for the period $58-43.5 \mathrm{ka}$ BP. If precipitation was less than today, a further expansion of forest in that period seems unlikely. The thermic contrasts between the poles and the equator in that period were similar when compared to the present-day situation (Sergin and Sergin, 1978). The reconstructed $\Delta Z_{0}$ for the time interval $58-43.5 \mathrm{ka}$ BP (245 - $332 \mathrm{~m}$; Table 4) was not large enough to suggest that the glaciers of the Mongun-Taiga massif disappeared completely. The climate during the MIS 3a stage in Tibet and north-western China was $2-4{ }^{\circ} \mathrm{C}$ warmer than today with a precipitation rate of $40-100 \%$ that of the present-day (Shi et al., 2008). The finds of buried wood having an age 25 - $27 \mathrm{ka}$ in the Mongun-Taiga massif (Revushkin, 1974) indicate that there were warm and moist conditions just before the onset of the MIS 2 glaciation. However, the altitude of the first sample $(3300 \mathrm{~m}$ a.s.l. $)$, that has a ${ }^{14} \mathrm{C}$ age of $27.5 \pm 0.180 \mathrm{ka} \mathrm{BP}$ is doubtful. The place of sampling was described as a moraine ridge of one of the latest glacial advances on the left side of the outlets of the Mugur river; but in fact all moraines there are located several hundred metres lower. Therefore, this find indicates warm conditions, but the reconstructed palaeotemperatures are not particularly reliable. The altitude of the second find $(29537-28759 \mathrm{cal}$ BP) at $2800 \mathrm{~m}$ a.s.l. seems more reliable. Consequently, the palaeo-reconstructions are based on 
525 this sample. We calculated for that period a doubling of the annual precipitation which is in 526 agreement with reconstructions of Murzaeva et al. (1984) and Malaeva (1995) for the Mongolian 527 Great Lakes depression. Under such conditions the reconstructed $\Delta \mathrm{Z}_{0}$ is only about $100 \mathrm{~m}$ and the 528 glacial cover would have been only slightly smaller than today.

529 The minimum summer insolation for $45^{\circ} \mathrm{N}$ was reached about $24-22$ ka ago (Clark et al., 2009).

530 The exact timing of the maximal glacier advance is large and varies from about 13 ka (Okishev, 531 2011) to 28 - 19 ka BP (Lehmkuhl et al., 2007). In southern Siberia, the summer temperatures 532 during the LGM were about $4{ }^{\circ} \mathrm{C}$ lower than today (Borzenkova, 1992) and in Tibet about $5{ }^{\circ} \mathrm{C}$ 533 lower (Shi et al., 2008). Okishev (2011) calculated a decrease in summer temperature of $3.8^{\circ} \mathrm{C}$ 534 which agrees with our estimation of $\Delta \mathrm{T}=-3.8^{\circ} \mathrm{C}$ (Table 4). Sheinkman (2011) assumed that the 535 glaciation in the Siberian mountains was mainly caused by cooling, because the ice sheets of north536 western Eurasia intercepted the Atlantic moisture. The altitudinal shift of the ELA varies in 537 literature from $-1200 \mathrm{~m}$ (Butvilovskiy, 1993) to $-610 \mathrm{~m}$ (Okishev, 2011) owing to different 538 palaeoglacial reconstructions. Our calculations of $\Delta Z_{0}$ for the MIS 2 maximum $(-658 \mathrm{~m})$ and the 539 information about the increased aridity in the Mongolian Great Lakes basin let us assume that 540 during the maximum and postmaximal stages of MIS 2 precipitation decreased (the calculated $P$ 541 values are in the range $43-46 \%$; Table 4). The cooling was most pronounced $\left(-3.8^{\circ} \mathrm{C}\right)$ in the Late 542 Pleistocene (MIS2 maximum, Table 4). If we assume a MIS 2 age of the LGM (assuming that the $543{ }^{10} \mathrm{Be}$ data are correct) then the calculated aridity and cooling would be even more distinct with $37 \%$ 544 and $-4.2^{\circ} \mathrm{C}$, respectively.

546 5.2. Climate and treeline variability during the Holocene

547 The discovered Pinus Sibirica trees trunks of the Vostotschniy (East) Mugur valley in the Mongun548 Taiga massif at an altitude of $2700 \mathrm{~m}$ have an age of 10180 - $10580 \mathrm{cal}$ BP (SOAN 8116) and 6170 $549-6350$ cal BP (SOAN- 8117; Nazarov et al., 2012; Table 2). Nowadays, the nearest Pinus Sibirica 550 stands are located $150-200 \mathrm{~km}$ to the west and $100 \mathrm{~km}$ to the north of the finding site. This 
551 indicates that the amount of precipitation was higher than today and would agree with the findings 552 of Blyakharchuk (2008). Our find of an ancient wood having an age of 9245 - 9000 cal BP (Table 553 2) in the same valley at an altitude of $2640 \mathrm{~m}$ a.s.l. refers to the same warm and moist period. This 554 is in agreement with findings of other alpine areas such as the European Alps where the treeline was 555 higher between about 10 to 4 ka BP mostly due to a warmer climate (Körner, 2012). The 556 reconstructed $\Delta T$ values $\left(2.0-2.4{ }^{\circ} \mathrm{C}\right)$, the doubling of precipitations (Table 4) and a $37-84 \mathrm{~m}$ rise 557 of the ELA indicate that the reconstructed area of glaciation was only $1-2 \mathrm{~km}^{2}$ smaller than today. 558 Warmer and moister conditions than today are indicated by a find of wood (Pinus Sibirica) having an age of $6170-6350 \mathrm{cal}$ BP (Table 2) that was discovered about $400 \mathrm{~m}$ higher than the presentday treeline (Nazarov et al., 2012). In contrast to this, drier conditions - leading to a forest decline (Rudaya et al., 2009) — were reconstructed for Mongolia between 7.11 and $4.39 \mathrm{ka}$ (Peck et al., 2002) and in the Uvs Nuur depression (about ka ago; Dorofeyuk and Tarasov, 1998; Grunert et al., 2000). For the mid-Holocene, $\Delta T$ is estimated from $2{ }^{\circ} \mathrm{C}$ (Borzenkova and Zubakov 1984) to $0.5{ }^{\circ} \mathrm{C}$ 564 (Velichko et al., 2009) in south-western to north-western Siberia and in the Altai. This matches well with our reconstructions. Charcoal finds (5445 - 5054 cal BP; Table 2) above the present-day treeline and a buried soil as a result of the first neoglacial advance (5881 - 5326 cal BP; Table 2) point to this warm period. We cannot exclude the possibility of a complete deglaciation of the massif during the late MIS 2 and early Holocene, although we have no evidence for this. A complete deglaciation seems to have occurred in the Mongolian Altai about 6 ka ago (Herren et al., 2013).

During the late Holocene, three glacial advances are usually distinguished in the Russian Altai: the Akkem stage, the 'Historical stage' and the Aktru stage (= LIA), which are considered either as 573 phases of the Last Glacial Epoch (Okishev, 2011) or as advances of glaciers that regenerated after the Holocene thermal optimum (Neoglacial; (Solomina, 1999; Agatova et al., 2012). The Akkem stage is dated to $4.3-4.0 \mathrm{ka} \mathrm{BP}$ (Galakhov et al., 2005), $4.4 \mathrm{ka} \mathrm{BP}$ (Okishev, 2011) and $4.9-4.2$ cal BP (Agatova et al., 2012). This is in general agreement with our findings. According to our ${ }^{14} \mathrm{C}$ 

dating (Table 2), a Neoglacial advance seemed to have occurred between 5.9 and 3.7 cal BP. The reconstructed average of $\Delta Z_{0}=-151 \mathrm{~m}$ and $\Delta Z_{0}{ }^{*}=-174 \mathrm{~m}$ do, however, not agree with Okishev (2011) who calculated 250 - $290 \mathrm{~m}$ for the different areas of the Russian Altai. This may be due to the different methods used. The approach used by Okishev (2011) may produce better results for valley glaciers but not for smaller cirque glaciers and flat-summit glaciers.

Most studies noted a change from arid to moister conditions at the transition from the Middle Holocene to the Neoglacial. According to Peck et al. (2002) the severest arid conditions in North Central Mongolia were between 7110 and 6260 cal BP, less arid conditions between $6260-4390$ cal BP, generally humid conditions after 4390 cal BP that was then followed by a more humid climate of 2710 - 1260 cal BP than today. In the Minusinsk and the Uyuk depressions in northern Tuva (Dirksen and van Geel, 2004) the climate became more humid $4-3$ ka BP. About 3 ka BP annual precipitation increased under relatively cold conditions (until $1.6 \mathrm{ka}$ BP). A moderately comparable trend was detected in the Uvs Nuur depression by Dorofeyuk and Tarasov (1998) and Grunert et al. (2000). Based on the temperature decrease $\left(\Delta T=-1^{\circ} \mathrm{C}\right)$, we obtained a precipitation rate that slightly exceeds the present-day situation $(P=110 \%)$. This agrees well with the increase in humidity after the mid-Holocene for the studied region. According to Agatova et al. (2012), a cooling and a minor glacial advance between 3.7 and $3.3 \mathrm{ka}$ BP may have occurred but we did not find any traces in the Mongun-Taiga that would confirm this.

The dated burials of soils (3141 - 2776 and 1293 - 1089; Table 2) are in relatively good agreement with the suggested advances at about $2500-3100$ (Galakhov et al., 2012) and around about $1700-$ 1800 years ago (Agatova et al., 2012; Galakhov et al., 2012).. According to Okishev (2011), $\Delta Z_{0}$ was $145-190 \mathrm{~m}$ for this Historical stage, which slightly exceeds our results $(120 \mathrm{~m})$. Okishev (2011) calculated a $\Delta \mathrm{T}$ of $-1{ }^{\circ} \mathrm{C}$ and Galakhov et al. (2005) a $\Delta \mathrm{T}$ of $-0.4^{\circ} \mathrm{C}$. When using the value $-0.4^{\circ} \mathrm{C}$ in our modelling, we obtain an increased precipitation $(119 \%)$ which agrees well with the Uvs Nuur transgression at that period (Dorofeyuk and Tarasov, 1998; Grunert et al., 2000). 
602 The last glacier advance in the Altai, the LIA or Aktry stage, occurred between the $13^{\text {th }}$ and the $19^{\text {th }}$ 603 century. The maximum LIA glacial advance in the Altai seems to have happened between the $17^{\text {th }}$ 604 and mid-19 th $^{\text {th }}$ century (Ivanovskiy and Panychev, 1978; Ivanovskiy et al., 1982; Ovchinnikov et al., 605 2002; Okishev, 2011; Nazarov et al., 2016). According to tree-ring measurements and related 606 climatic reconstructions (Myglan et al., 2012) the lowest summer temperatures in the Mongun607 Taiga massif were determined for the period 1788 - 1819. Based on dendrochronological 608 reconstructions (Ganyushkin et al., 2015), the maximum glacial advance took place at the beginning 609 of the $19^{\text {th }}$ century and the glaciers started to retreat after about $1810-1820$ AD. Okishev (2011) 610 gives for the Russian Altai an average $\Delta Z_{0}$ value of $70 \mathrm{~m}$. Lehmkuhl (2012) obtained for the Turgen 611 and Kharkhiraa massifs (Mongolia) a reconstructed $\triangle$ ELA of 81 and $76 \mathrm{~m}$, respectively. During the 612 last millennia, the treeline position did not change distinctly (Kharuk et al., 2010) because the 613 oscillation of climate was not that strong and treeline position always lags behind climatic change 614 by at least 50, and possibly up to more than 100 years (Körner, 2012).

615 The reconstructed $\Delta \mathrm{T}$ values for the LIA maximum in the Altai are -2 to $-2.5^{\circ} \mathrm{C}$ (Adamenko, $6161985),-0.4^{\circ} \mathrm{C}\left(\right.$ Okishev, 2011) and -0.8 to $-0.9^{\circ} \mathrm{C}$ (Okishev, 1985). Summer temperature (June, 617 July) did not seem to have fluctuated that much but winter and mean annual temperatures strongly 618 increased since the LIA in the Altai (Schwikowski et al., 2009). According to Ganyushkin et al. 619 (2015), the climate of the Mongun-Taiga massif was relatively cold and dry during the LIA 620 maximum $\left(\Delta \mathrm{T}=-1.3{ }^{\circ} \mathrm{C}, \mathrm{P}=73 \%\right)$. This value correlates well with data from Barnaul, the 621 longest-running meteorological station in the Altai region.

\section{Conclusions}

624 Using published and our new data, a chronology of glaciation and the reconstruction of climatic 625 fluctuations in the Mongun Taiga (Altai) was rendered possible for the about the last about $80 \mathrm{ka}$. 626 We determined high amplitudes of climatic, glacial and treeline changes. The variability (compared 627 to the present-day climate) of summer temperatures ranged from $-3.8(-4.2)$ to $+3.0^{\circ} \mathrm{C}$, 
precipitation from 43 (37) to $200 \%$, the ELA from - 1200 to $460 \mathrm{~m}$ and the upper treeline from 550 to $470 \mathrm{~m}$. The amount of precipitation was the main factor that determined the timing of the maximal glacial advance in Late Pleistocene. It seems that the MIS 3c and MIS 3a stages were extraordinarily warm. The distinctly elevated treeline during that time evidences that the glaciers retreated to probably high altitudes and covered only a small area. The maximum glacier extent was probably during MIS 4. There is no evidence of a complete disappearance of the glaciers even in the warmest periods of the Late Pleistocene. The precise dating of the LGM, however, still remains open and additional ${ }^{10} \mathrm{Be}$ dates (on suitable boulders) are needed. During several periods, forest vegetation occupied larger areas than today. The actual tendency of warming and increase in precipitation after the LIA maximum probably will lead to a wider expansion of forests.

\section{Acknowledgements}

This work was supported by the Saint-Petersburg state University [grant number 18.38.418.2015], the Russian Foundation for Basic Research [grant number 15-05-06611], the All-Russian Public Organization 'Russian Geographical Society' within the framework of the scientific project No. 08/2016-I and by a grant of the Scientific \& Technological Cooperation Programme SwitzerlandRussia (University of Geneva, nr. 37061135). We are, furthermore, indebted to two unknown reviewers for their helpful comments on an earlier version of the manuscript.

\section{References}

Adamenko, M.F., 1985. Reconstruction of Summer Temperature Variability and Glacier Dynamics in the Gorniy Altai for Period 14th-20th Centuries. Ph.D. thesis, Press of SBRAS Institute of Geology and Geophysics, Novosibirsk,USSR (in Russian).

Agatova, A.R., Nepop, R.K., Khazina, I.V., Khazin, L.B., 2009. The possibility of the tie correlation of Gorny Altai glaciations to SPECMAP time scale and south Siberia glaciations, in: VI All-Russian Meeting on the Study of the Quaternary Period. pp. 18-20. 
654 Agatova, A.R., Nazarov, A.N., Nepop, R.K., Rodnight, H., 2012. Holocene glacier fluctuations and 655 climate changes in the southeastern part of the Russian Altai (South Siberia) based on a 656

Agatova, A.R., Nepop, R.K., Slyusarenko, I.Yu, Myglan, V.S., Nazarow, A.N., Barinov, V.V., 2014. Glacier dynamics, palaeohydrological changes and seismicity in southeastern Altai (Russia) and their influence on human occupation during the last 3000 years. Quaternary International 324, 6-19.

661 Agatova, A.R., Nepop, R.K., 2017. Pleistocene glaciations of the SE Altai, Russia, based on 662 geomorphological data and absolute dating of glacial deposits in Chagan reference section. 663 Geochronometria 44, 49-65. doi:10.1515/geochr-2015-0059

664 Arslanov, KH.A., Tertychnaya, T.V., Chernov, S.B., 1993. Problems and methods of dating low665 activity samples by liquid scintillation counting. Radiocarbon 35, 393-398.

666 Blyakharchuk, T. A., 2008. Reconstructing the vegetation of forest and alpine-steppe landscapes in 667 the southwestern part of Tuva since the Late Glacial period till the present. Geography and $668 \quad$ Natural Resources 29, 57-62.

669 Böhlert, R., Egli, M., Maisch, M. Brandová, D., Ivy-Ochs, S., Kubik, P.W., Haeberli, W. 2011. 670 Application of a combination of dating techniques to reconstruct the Lateglacial and early 671 Holocene landscape history of the Albula region (eastern Switzerland). Geomorphology 127, 1672 13.

673 Borchers, B., Marrero, S., Balco, G., Caffee, M., Goehring, B., Lifton, N., Nishiizumi, K., Phillips, 674 F., Schaefer, J., Stone, J., 2016. Geological calibration of spallation production rates in the 675 CRONUS-Earth. Quaternary Geochronology 31, 188-198.

676 Borisov, B.A., Minina, E.A., 1989. Plejstocenovye oledenenija Altae-Sajanskoj gornoj strany i ih korreljacija i rekonstrukcii, in: Paleoklimaty I Oledenenija v Plejstocene. Nauka, Moscow, pp. 217-223. 
Borzenkova, I.I., 1984. The climate optimum of the Holocene as a model of the beginning of the 21st century. Meteorol. i Gidrol. 8, 69-77 (in Russian).

Borzenkova, I.I., 1992. Izmenenie klimata v kajnozoe. Hydrometeoizdat, Saint-Petersburg.

Bronk Ramsey, C., 2001. Development of the radiocarbon calibration program. Radiocarbon 43, $355-363$.

Bronk Ramsey, C., 2009. Bayesian analysis of radiocarbon dates. Radiocarbon 51, 337-360.

Brown, E.T., Edmond, J.M., Raisbeck, G.M., Yiou, F., Desgarceaux, S., 1992. Effective attenuation length of cosmic rays producing ${ }^{10} \mathrm{Be}$ and ${ }^{26} \mathrm{Al}$ in quartz: implications for surface exposure dating. Geophysical Research Letters 9, 369-372.

Butvilovskiy, V. V., 1993. Paleogeografiya poslednego oledenenija i holozena Altaja: sobytiynokatastroficheskaja model'. T.U., Tomsk.

Chistyakov, K. V., Seliverstov, Y.P., 1999. Regional'naja ekologija maloizmenennyh landshaftov: Severo-Zapad Vnutrennej Azii. Izdatel'stvo SPbGU, Saint-Petersburg.

Chistyakov, K.V., Ganyushkin, D.A., Moskalenko, I.G., Zelepukina, E.S., Amosov, M.I., Volkov, I.V., Glebova, A.B., Guzjel', N.I., Zhuravlev, S.A. Prudnikova, T.N., Prjahina, G.V., 2012. Gornyj massiv Mongun-Tajga. V.V.M., Saint-Petersburg.

Christl, M., Vockenhuber, P.W., Kubik, P.W., Wacker, L., Lachner, J., Alfimov, V., Synal, H.-A., 2013. The ETH Zurich AMS facilities: Performance parameters and reference materials. Nuclear Instruments and Methods in Physics Research B 294, 29-38.

Clark, P.U., Clark, P.U., Dyke, A.S., Shakun, J.D., Carlson, A.E., Clark, J., Wohlfarth, B., Mitrovica, J.X., Hostetler, S.W., Mccabe, A.M., 2009. The Last Glacial Maximum. Science 325, 710-714. doi:10.1126/science. 1172873

Devyatkin, E., 1965. Cenozoic deposits and neotectonics of southeastern Altai. Proc. GIN AN SSSR 126, 244.

Devyatkin, E. V., 1981. The Cenozoic of Inner Asia (in Russian). Publ. H. Nauka, Moscow. 
Dirksen, V.G., van Geel, B., 2004. Mid to late Holocene climate change and its influence on cultural development in South Central Siberia, in: Scott, E.M., Alekseev, A.Y., Zaitseva, G. (Eds.), Impact of the Environment on Human Migration in Eurasia. NATO Science Series, IV. Earth and Environmental Sciences 42, pp. 159-183.

Dorofeyuk, N.I., Tarasov, P.E., 1998. Vegetation and lake levels in Northern Mongolia in the last 12,500 years as indicated by data of pollen and diatom analysis. Stratigr. Geol. Correl. $70-83$.

Galakhov, V.P., Nazarov, A.N., Kharlamova, N.F., 2005. Kolebanija lednikov i izmenenija klimata v pozdnem golocene po materialam issledovanij lednikov i lednikovyh otlozhenij bassejna Aktru (Central'nyj Altaj, Severo-Chujskij hrebet). izdatel'stvo Altajskogo universiteta, Barnaul.

Galakhov, V.P., Chernykh, D. V., Zolotov, D. V., Orlova, L.A., 2012. Polozhenie i vremja formirovanija moren stadij fernau i istoricheskoj v bassejne reki Hajdun na Altae. Izv. Rus. Geogr. Obs. 144, 15-21.

Ganiushkin, D., Chistyakov, K., Kunaeva, E., 2015. Fluctuation of glaciers in the southeast Russian Altai and northwest Mongolia Mountains since the Little Ice Age maximum. Environ. Earth Sci. 74, 1883-1904. doi:10.1007/s12665-015-4301-2

Ganyushkin, D.A., 2015. Gljaciogennye kompleksy rezkokontinental'nogo rajona severo-zapada Vnutrennej Azii. Glacigenic complexes of sharply continental area of north-west Inner Asia. Saint-Petersburg state university, Saint-Petersburg.

Glazyrin, G.E., 1985. Raspredelenie i rezhim gornyh lednikov. Hydrometeoizdat, Leningrad.

Gosse, J.C., Phillips, F.M., 2001. Terrestrial in situ produced cosmogenic nuclides: Theory and application. Quaternary Science Reviews 20, 1475-1560.

Goudie, A.S., 2006. The Schmidt Hammer in geomorphologlical research. Prog. Phys. Geogr. 30, 703-718. doi:10.1177/0309133306071954

Gribenski, N., Jansson, K.N., Lukas, S., Stroeven, A.P., Harbor, J.M., Blomdin, R., Ivanov, M.N., Heyman, J., Petrakov, D.A., Rudoy, A., Clifton, T., Lifton, N.A., Caffee, M.W., 2016. Complex 
729 patterns of glacier advances during the late glacial in the Chagan Uzun Valley, Russian Altai.

730 Quat. Sci. Rev. 149, 288-305. doi:10.1016/j.quascirev.2016.07.032

731 Grunert, J., Lehmkuhl, F., Walther, M., 2000. Paleoclimatic evolution of the Uvs Nuur basin and 732 adjacent areas (Western Mongolia). Quat. Int. 65-66, 171-192. doi:10.1016/S1040$733 \quad 6182(99) 00043-9$

734 Herget, J., Carling, P., Agatova, A., Batbaatar, J., Borodavko, P., Gillespie, A., Nepop, R., 2017. 735 Comment on Gribenski, N. et al., 2016. Complex patterns of glacier advances during the late 736 glacial in the Chagan Uzun Valley, Russian Altai. Quaternary Science Reviews 149, 288-305. Quat. Sci. Rev. 168, 216-219. doi:10.1016/j.quascirev.2017.04.014

Herren, P.A., Eichler, A., Machguth, H., Papina, T., Tobler, L., Zapf, A., Schwikowski, M., 2013. The onset of Neoglaciation 6000 years ago in western Mongolia revealed by an ice core from the Tsambagarav mountain range. Quat. Sci. Rev. 69, 59-68. doi:10.1016/j.quascirev.2013.02.025

741 IACS, 2011. Glossary of Glacier Mass Balance and Related Terms. Int. Hydrol. Program. United Nations Educ. Sci. Cult. Organ. 86, 114.

Ivanovskiy, L.N., Panychev, V.A., 1978. Razvitie i vozrast konechnyh moren XVII-XIX vv. lednikov Ak-Turu na Altae, in: Processy Sovremennogo Rel'efoobrazovanija v Sibiri. Nauka, Irkutsk, pp. 127-138.

Ivanovskiy, L.N., Panychev, V.A., Orlova, L.A., 1982. Vozrast konechnyh moren stadij «Aktru» i «Istoricheskoj» lednikov Altaja, in: Pozdnij Plejstocen I Golocen Juga Vostochnoj Sibiri. Nauka, Novosibirsk, pp. 57-64.

Ivy-Ochs, S., Kober, F., 2008. Surface exposure dating with cosmogenic nuclides. Quaternary Science Journal 57, 157-189.

Kharuk, V.I., Im, S.T., Dvinskaya, M.L., Ranson, K.J., 2010. Climate-induced mountain tree-line evolution in southern Siberia. Scandinavian Journal of Forest Research 25, 446-454. 
753 Klinge, M., 2001. Glacial-geomorphologic Investigations in the Mongolian Altai: a Contribution to 754 the Late Quaternary Landscape and Climate History of Western Mongolia. Aachener 755 Geographische Arbeiten, Aachen.

756 Körner, C., 2012. Alpine Treelines. Functional Ecology of the Global High Elevation Tree Limits. 757 Springer, Basel.

758 Korschinek, G., A. Bergmaier, A., Faestermann, T., Gerstmann, U.C., Remmert, A., 2010. A new 759 value for the half-life of ${ }^{10} \mathrm{Be}$ by Heavy-Ion Elastic Recoil Detection and liquid scintillation 760 counting. Nuclear Instruments and Methods in Physics Research Section B: Bean Interaction $761 \quad$ with Materials and Atoms 268, 187-191.

762 Kubik, P.W., Christl, M., 2010. ${ }^{10} \mathrm{Be}$ and ${ }^{26} \mathrm{Al}$ measurements at the Zurich 6 MV Tandem AMS 763 facility. Nuclear Instruments and Methods B 268, 880-883.

764 Lal, D., 1991. Cosmic ray labeling of erosion surfaces: in situ nuclide production rates and erosion 765 models. Earth Planet. Sci. Lett. 104, 424-439.

766 Lehmkuhl, F., Liu, S., 1994. An outline of physical geography including Pleistocene glacial 767 landforms of Eastern Tibet (provinces Sichuan and Qinghai). GeoJournal 34, 7-30. doi:10.1007/BF00813966.

769 Lehmkuhl, F., Zander, A., Frechen, M., 2007. Luminescence chronology of fluvial and aeolian 770 deposits in the Russian Altai (Southern Siberia). Quat. Geochronol. 2, 195-201. doi:10.1016/j.quageo.2006.04.005.

Lehmkuhl, F., Klinge, M., Rother, H., Hülle, D., 2016. Distribution and timing of Holocene and late Pleistocene glacier fluctuations in western Mongolia. Annals of Glaciology 57, 169-178.

Malaeva, E.M., 1995. Ob izmenchivosti klimaticheskogo rezhima Gornogo Altaja v pozdnem plejstocene i paleogljaciologicheskih rekonstrukcijah. Geomorfologija 51-60.

Masarik, J., Frank, M., Schaefer, J.M., Wieler, R., 2001. Correction of in-situ cosmogenic nuclide production rates for geomagnetic field intensity variations during the past 800,000 years. Geochimica et Cosmochimica Acta 65, 2995-3003. 
779 Matthews, J.A., Shakesby, R.A., 1984. The status of the 'Little Ice Age' in southern Norway: 780 relative age dating of Neoglacial moraines with Schmidt hammer and lichenometry. Boreas 13, $781 \quad 333-346$. doi:10.1111/j.1502-3885.1984.tb01128.x

782 Mihaelis, E.P., 1886. An ice-period in Altai mountains. Nature 35, 149.

783 Murzaeva, V.E., Konopleva, V.I., Devyatkin, E.V., Serebrjanyj, L.R., 1984. Pljuvial'nye 784 obstanovki pozdnego plejstocena i golocena v aridnoj zone Azii i Afriki. Izv. AN SSSR, Ser. 785 Geogr. 15-25.

786 Myglan, V.S., Oidupaa, O.C., Vaganov, E.A., 2012. A 2367-year tree-ring chronology for the 787 Altay-Sayan region (Mongun-Taiga Mountain Massif). Archaeol. Ethnol. Anthropol. Eurasia 40, $788 \quad 76-83$.

789 Nazarov, A.N., Myglan, V.S., Orlova, L.A., Ovchinnikov, I.Y., 2016. Aktivnost' lednika Malyj $790 \quad$ Aktru (Central'nyj Altaj) i izmenenija granicy lesa v bassejne Aktru za istoricheskij period. Led i $791 \quad$ sneg $56,103-118$.

792 Nazarov, A.N., Solomina, O.N., Myglan, V.S., 2012. Dinamika verhnej granicy lesa i lednikov 793 Central'nogo i Vostochnogo Altaja v golocene. Dokl. Akad. Nauk 444, 1-5.

794 Nishiizumi, K., Imamura, M., Caffee, M.W., Southon, J.R., Finkel, R.C., McAninch, J., 2007. 795 Absolute calibration of ${ }^{10} \mathrm{Be}$ AMS standards, Nuclear Instruments and Methods. B 258, 403-413. 796 Obruchev, V.A., 1914. Altai sketches (sketch first). Notes on the traces of ancient glaciation in the 797 Russian Altai. Altajskie jetjudy (jetjud pervyj). Zametki o sledah drevnego oledenenija v $798 \quad$ Russkom Altae. Zemlevedenie 50-97.

799 Okishev, P.A., 1982. Dynamics of Altai glaciation in the Late Pleistocene and Holocene. T.U., $800 \quad$ Tomsk.

801 Okishev, P.A., 1985. Malyj lednikovyj period na Altae. Mater. gljaciologicheskih Issled. 170-174. 802 Okishev, P.A., 2011. Rel'ef i oledenenie Russkogo Altaja. Izd. Tom. un-ta, Tomsk. 
803 Ovchinnikov, D.V., Panyushkina, I.P., Adamenko, M.F., 2002. Millennial Larch Tree-Ring 804 Chronology for Mountain Altai and Its Use for Reconstructing Summer Temperatures. Geogr. $805 \quad$ Nat. Resour. 102-108.

806 Peck, J. a, Khosbayar, P., Fowell, S.J., Pearce, R.B., Ariunbileg, S., Hansen, B.C.S., Soninkhishig, 807 N., 2002. Mid to Late Holocene climate change in north central Mongolia as recorded in the 808 sediments of Lake Telmen. Palaeogeogr. Palaeoclimatol. Palaeoecol. 183, 135-153. 809 doi:10.1016/S0031-0182(01)00465-5

810 Pettitt, P.B., White, M., 2012. The British Palaeolithic: Human Societies at the Edge of the 811 Pleistocene World. Routledge, Abingdon.

812 Pigati, J.S., Lifton, N.A., 2004. Geomagnetic effects on time-integrated cosmogenic nuclide 813 production with emphasis on in situ ${ }^{14} \mathrm{C}$ and ${ }^{10} \mathrm{Be}$. Earth and Planetary Science Letters 226, 193814205.

815 Reimer, P.J., Bard, E., Bayliss, A., Beck, J.W., Blackwell, P.G., Bronk Ramsey, C., Buck, C.E., 816 Cheng, H., Edwards, R.L., Friedrich, M., Grootes, P.M., Guilderson, T.P., Haflidason, H., 817 Hajdas, I., Hatté, C., Heaton, T.J., Hoffmann, D.L., Hogg, A.G., Hughen, K.A., Kaiser, K.F., 818 Kromer, B., Manning, S.W., Nui, M., Reimer, R.W., Richards, D.A., Scott, E.M., Southon, J.R., 819 Staff, AR.A., Turney, C., van der Plicht, J., 2013. IntCal13 and Marine13 radiocarbon age 820 calibration curves 0-50,000 years cal BP. Radiocarbon 55, 1869-1887.

821 Reuther, A.U., Herget, J., Ivy-Ochs, S., Borodavko, P., Kubik, P.W., Heine, K., 2006. Constraining 822 the timing of the most recent cataclysmic flood event from ice-dammed lakes in the Russian 823 Altai Mountains, Siberia, using cosmogenic in situ 10Be. Geology 34, 913. 824 doi:10.1130/G22755A.1

825 Revushkin, A.S., 1974. O nahodke iskopaemoj drevesiny na hrebte Mongun-Tajga (Jugo-Zapadnaja 826 Tuva). Izv. Sib. Otd. AN SSSR serija bil, 46-47. 
827 Rother, H., Lehmkuhl, F., Fink, D., Nottebaum, V., 2014. Surface exposure dating reveals MIS-3 828 glacial maximum in the Khangai Mountains of Mongolia. Quat. Res. 82, 297-308. doi:10.1016/j.yqres.2014.04.006

830 Rudaya, N., Tarasov, P., Dorofeyuk, N., Solovieva, N., Kalugin, I., Andreev, A., Daryin, A., 831 Diekmann, B., Riedel, F., Tserendash, N., Wagner, M., 2009. Holocene environments and 832 climate in the Mongolian Altai reconstructed from the Hoton-Nur pollen and diatom records: a 833 step towards better understanding climate dynamics in Central Asia. Quat. Sci. Rev. 28, 540834 554. doi:10.1016/j.quascirev.2008.10.013

835 Ruddiman, W.F., McIntyre, A., 1981. Oceanic mechanisms for amplification of the 23,000-year 836 ice-volume cycle. Science 212, 617-627. doi: 10.1126/science.212.4495.617.

837 Schmidt, E., 1951. A non-destructive concrete tester. Concrete 59(8), 34-35.

838 Schwikowski, M., Eichler, A., Kalugin, I., Ovtchinnikov, D., Papina, T., 2009. Past climate 839 variability in the Altai. PAGES News 17, 44-45.

840 Sergin, V.J., Sergin, S.J., 1978. Sistemnyj analiz programmy bol'shih kolebanij klimata i 841 oledenenija zemli. Hydrometeoizdat, Leningrad.

842 Shakesby, R.A., Matthews, J.A., Owen, G., 2006. The Schmidt hammer as a relative-age dating tool 843 and its potential for calibrated-age dating in Holocene glaciated environments. Quat. Sci. Rev. $844 \quad 2846-2867$.

845 Sheinkman, V.S., 2002. Testing the S-S technique of TL dating on the Dead Sea sections, its use in 846 the Altai Mountains and palaeogeographic interpretation of results. Archeol. Ethnogr. 10, 22-37. 847 Sheinkman, V.S., 2011. Glaciation in the high mountains of Siberia. In: Ehlers, J., Gibbard, P.L., 848 Hughes, P.D. (eds.), Quaternary glaciations - extent and chronology - A closer look. 849 Developments in Quaternary Science 15, 883-907.

850 Shi, Y., Huang, M., Yao, T., He, Y., 2008. Glaciers and related environments in China. Sience 851 Press, Beijing.

852 Solomina, O.N., 1999. Gornye ledniki Severnoj Evrazii v Golocene. Nauchnyj mir, Moscow. 
853 Stone, J.O., 2000. Air pressure and cosmogenic isotope production. Journal of Geophysical $854 \quad$ Research 105/B10(23), 753-759.

855 Svitoch, A.A., Faustov, S.S., 1978. Rezul'taty izuchenija novejshih otlozhenij nekotoryh razrezov 856 Chujskoj vpadiny v svjazi s istoriej oledenenija Gornogo Altaja, in: Sovremennoe I Drevnee 857 Oledenenie Ravninnyh I Gornyh Rajonov SSSR (Sbornik Statej). Izd-vo GO SSSR, pp. 114$858 \quad 124$.

859 Thompson, L.G., 1997. Tropical Climate Instability: The Last Glacial Cycle from a Qinghai860 Tibetan Ice Core. Science (80-. ). 276, 1821-1825. doi:10.1126/science.276.5320.1821

861 Van Meerbeeck, C.J., Renssen, H., Roche, D.M., 2008. How did Marine Isotope Stage 3 and Last 862 Glacial Maximum climates differ? Perspectives from equilibrium simulations. Clim. Past 863 Discuss. 4, 1115-1158. doi:10.5194/cpd-4-1115-2008

864 Velichko, A.A., Klimanov, V.A., Borzenkova, I.., 2009. Klimaticheskie harakteristiki golocena 865 (6000-5500 1.n.) (karty 6-10), in: Paleoklimaty I Paleolandshafty Vnetropicheskogo Prostranstva 866 Severnogo Polusharija. Pozdnij Plejstocen - Golocen. Atlas-Monografija. Geos, Moscow, pp. $867 \quad 20-24$.

868 Voelker, A.H.L., Workshop participants, 2002. Global distribution of centennial scale records for 869 Marine Isotope Stage (MIS) 3: a database. Quat. Sci. Rev. 21,1185-1212.

870 von Blanckenburg, F., Belshaw, N.S., O'Nions, R.K., 1996. Separation of ${ }^{9}$ Be and cosmogenic ${ }^{10}$ Be 871 from environmental materials and SIMS isotope dilution analysis. Chemical Geology 129, 9387299.

873 Xu, X., Yang, J., Dong, G., Wang, L., Miller, L., 2009. OSL dating of glacier extent during the Last 874 Glacial and the Kanas Lake basin formation in Kanas River valley, Altai Mountains, China. 875 Geomorphology 112, 306-317. doi:10.1016/j.geomorph.2009.06.016

876 Zhao, J., Yin, X., Harbor, J.M., Lai, Z., Liu, S., Li, Z., 2013. Quaternary glacial chronology of the 877 Kanas River valley, Altai Mountains, China. Quat. Int. 311, 44-53. 878 doi:10.1016/j.quaint.2013.07.047 


\section{Figure captions}

Fig. 1. Orographic map of the Mongun-Taiga massif and neighbouring mountain ranges with the insert in the upper left showing the study area on the Eurasian continent.

Fig. 2. Reconstruction of palaeoglaciation of the Mongun-Taiga massif. 1: main summit of the massif, 2: mountain ridges and watersheds, 3: rivers, 4: lakes, 5: forested areas, 6: hypothesised extent of glaciers during MIS 4 (based on geomorphic mapping and results given Tables 1 and 2), 7: hypothesised extent of glaciers during MIS 2 (based on geomorphic mapping and results given Tables 1 and 2), 8: LIA glaciers, 9: present-day glaciers. The red frame (inlet) refers to the area 891 plotted in Fig. 3.

Fig. 3. Main sampling locations on the north-eastern slope of the Mongun-Taiga massif. The indices in the map correspond with those in Table 2. Topographic and geomorphic features: 1: main summits of the massif, 2: contour lines, 3: river flow direction, 4: rivers, 5: lakes, 6: present-day glaciers, 7: forested areas, 8: traces of MIS 6 (?) moraines; 9: moraines of group I (hypothesised to be deposited during MIS 4), 10: moraines of group II (hypothesised to be deposited during MIS 2), 11: moraines of group III (neoglacial). Sample categories (sampling site): A: locations of buried $899 \operatorname{wood}(1,2,3,4,5,6,7,14)$, B: soils $(8,9,10,11,12)$, C: peat (several sites: 13, 14, 15), and D: 900 boulders.

Fig. 4. Trunk of a Larix Sibirica (category A (buried wood), site 2 (LU-3666) in Fig. 3) having an age (1- $\sigma$ range) of $43688-42567$ cal BP (photo by authors, 1999). 
905 Fig. 5. Reconstruction of temperature fluctuations, precipitation, ELA and the elevation of the 906 upper treeline (with corrections for tectonic uplift). Red line: temperature, relative to the present907 day climate $\Delta T^{*}\left({ }^{\circ} \mathrm{C}\right)$; Blue line: precipitation at the current ELA, $P(\mathrm{~mm})$; Green line: upper 908 treeline, $\Delta F^{*}(\mathrm{~m})$ (relative to present-day elevation); Black line: ELA, $\Delta Z_{0}{ }^{*}(\mathrm{~m})$ relative to present909 day level. 


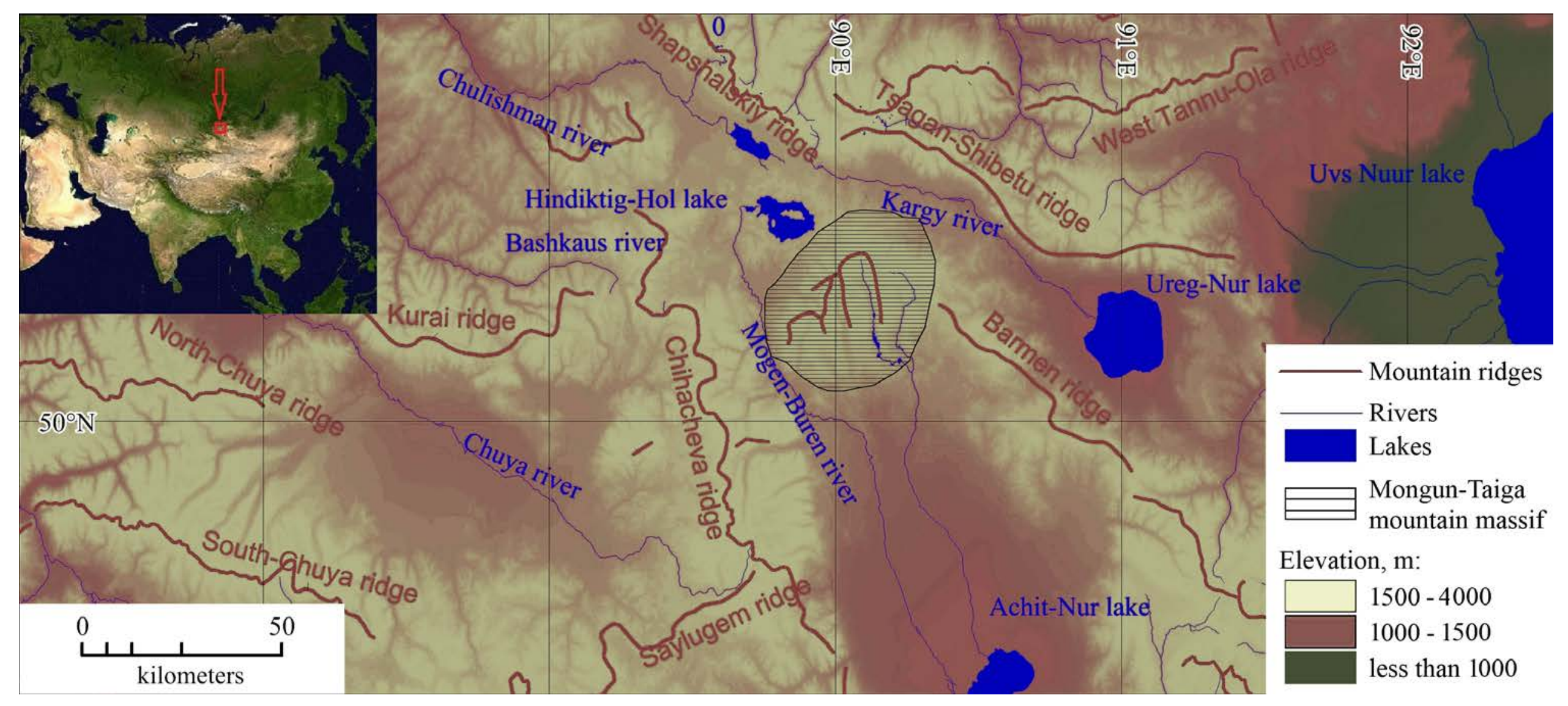




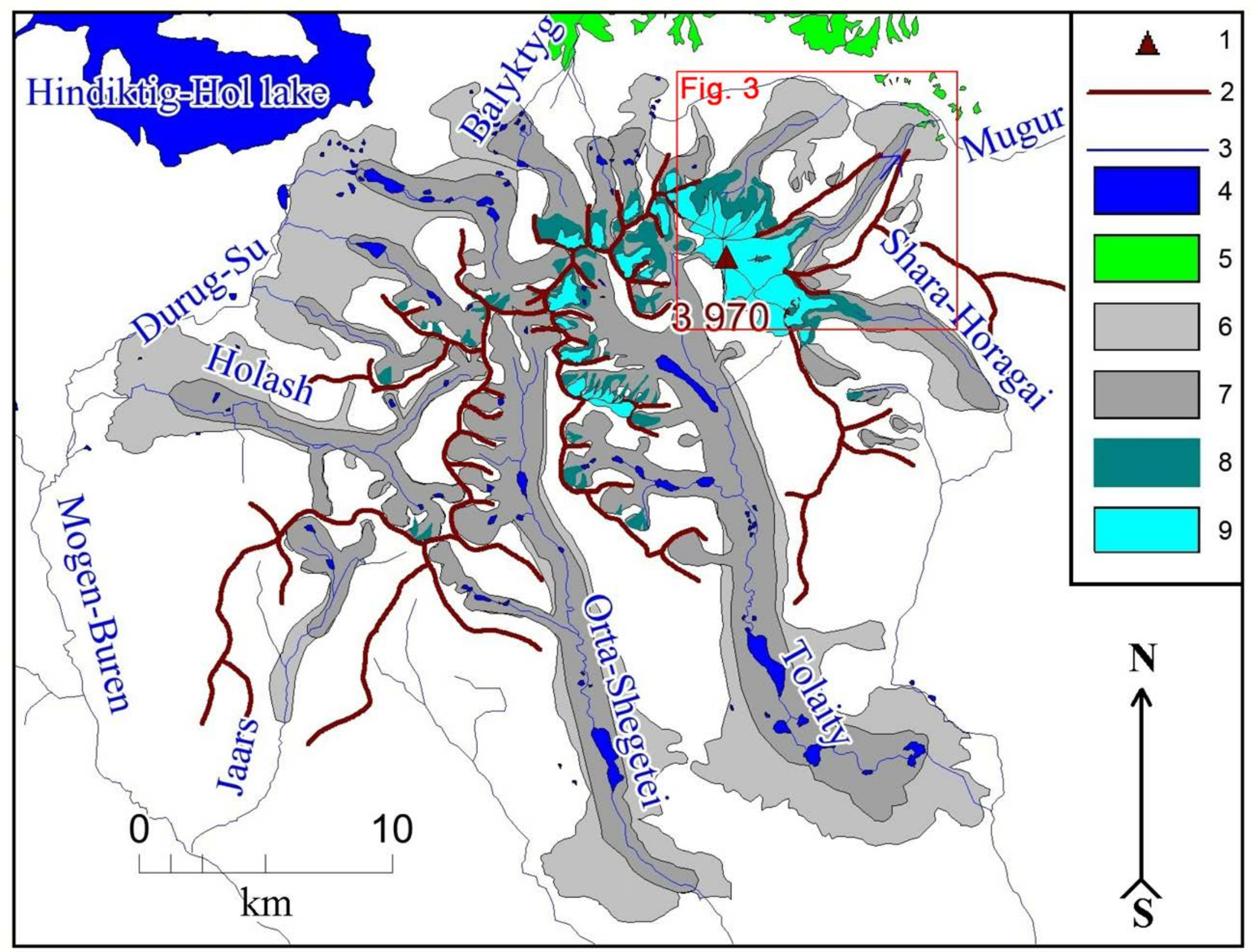




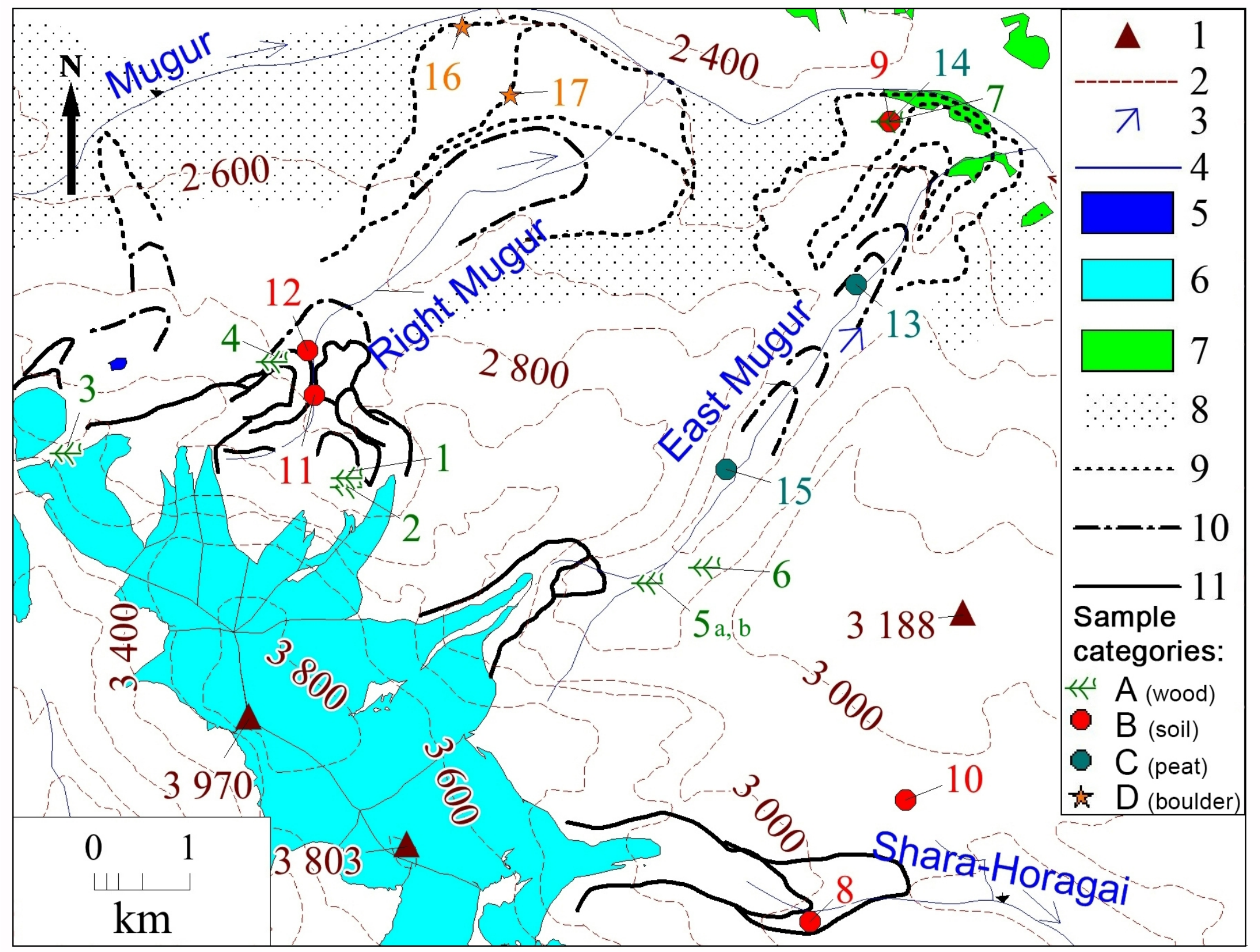




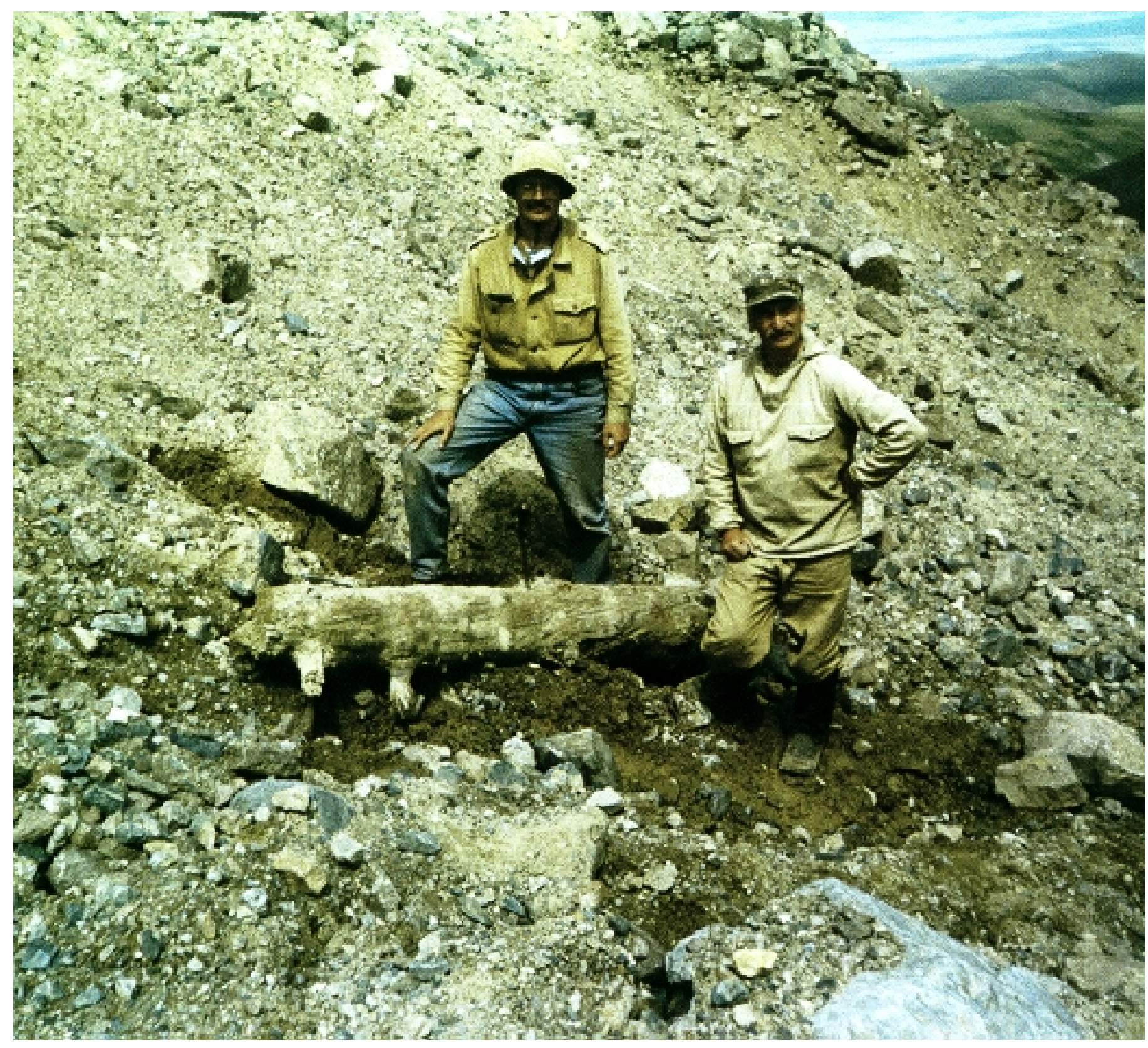




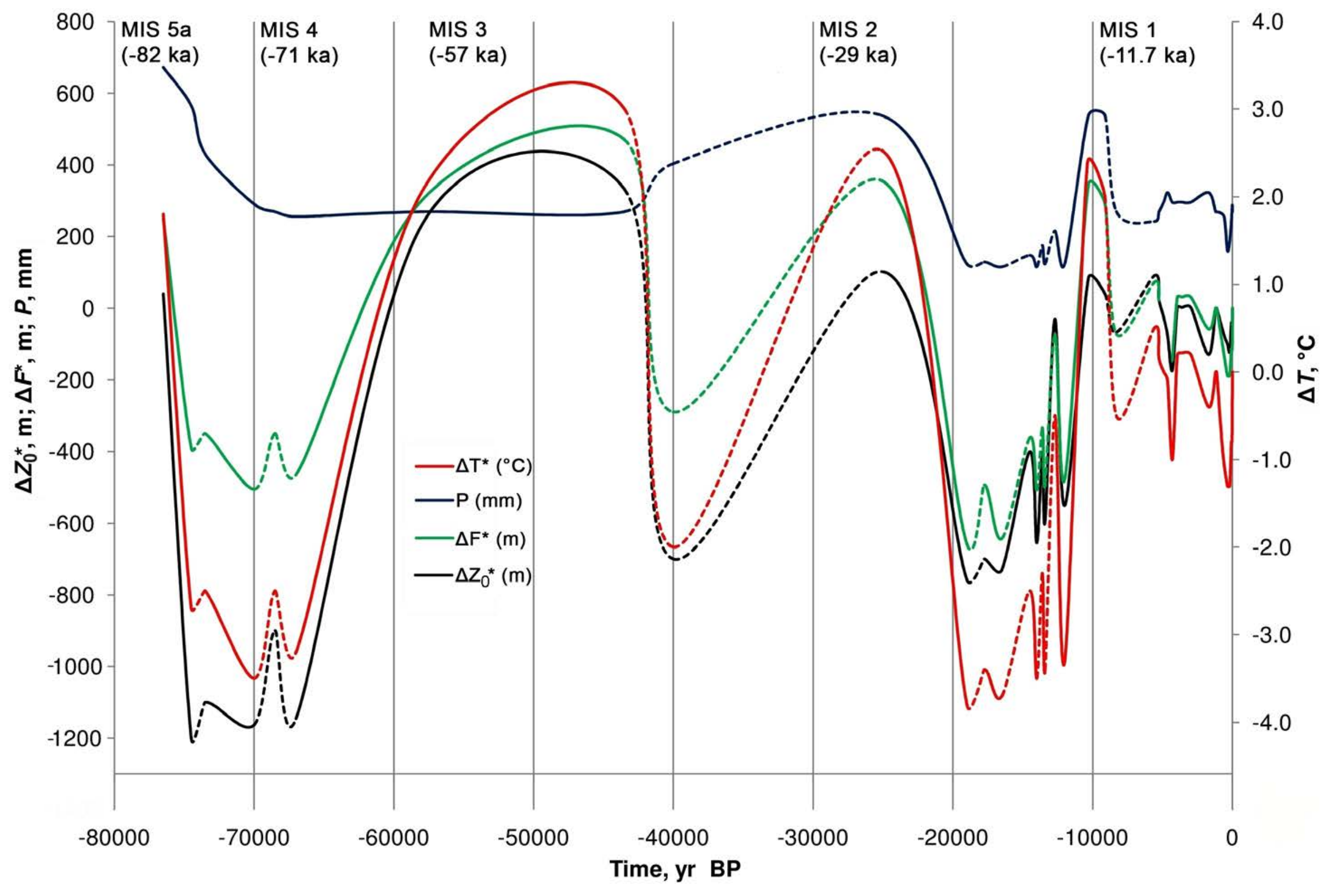

